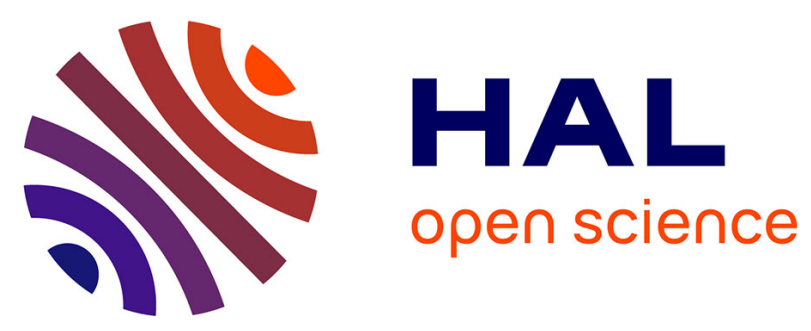

\title{
Multiscale observations of NH3 around Toronto, Canada
}

Shoma Yamanouchi, Camille Viatte, Kimberly Strong, Erik Lutsch, Dylan B.

A. Jones, Cathy Clerbaux, Martin Van Damme, Lieven Clarisse, Pierre-François Coheur

\section{- To cite this version:}

Shoma Yamanouchi, Camille Viatte, Kimberly Strong, Erik Lutsch, Dylan B. A. Jones, et al.. Multiscale observations of NH3 around Toronto, Canada. Atmospheric Measurement Techniques, 2021, 14 (2), pp.905-921. 10.5194/amt-14-905-2021 . insu-02926968v2

\section{HAL Id: insu-02926968 \\ https://hal-insu.archives-ouvertes.fr/insu-02926968v2}

Submitted on 5 Feb 2021

HAL is a multi-disciplinary open access archive for the deposit and dissemination of scientific research documents, whether they are published or not. The documents may come from teaching and research institutions in France or abroad, or from public or private research centers.
L'archive ouverte pluridisciplinaire HAL, est destinée au dépôt et à la diffusion de documents scientifiques de niveau recherche, publiés ou non, émanant des établissements d'enseignement et de recherche français ou étrangers, des laboratoires publics ou privés. 


\title{
Multiscale observations of $\mathrm{NH}_{3}$ around Toronto, Canada
}

\author{
Shoma Yamanouchi ${ }^{1}$, Camille Viatte $^{2}$, Kimberly Strong ${ }^{1}$, Erik Lutsch $^{1}$, Dylan B. A. Jones ${ }^{1}$, Cathy Clerbaux $^{2}$, \\ Martin Van Damme ${ }^{3}$, Lieven Clarisse ${ }^{3}$, and Pierre-Francois Coheur ${ }^{3}$ \\ ${ }^{1}$ Department of Physics, University of Toronto, Toronto, Ontario, Canada \\ ${ }^{2}$ LATMOS/IPSL, Sorbonne Université, UVSQ, CNRS, Paris, France \\ ${ }^{3}$ Spectroscopy, Quantum Chemistry and Atmospheric Remote Sensing (SQUARES), Université Libre \\ de Bruxelles (ULB), Brussels, Belgium
}

Correspondence: Shoma Yamanouchi (syamanou@physics.utoronto.ca)

Received: 7 August 2020 - Discussion started: 31 August 2020

Revised: 22 November 2020 - Accepted: 18 December 2020 - Published: 5 February 2021

\begin{abstract}
Ammonia $\left(\mathrm{NH}_{3}\right)$ is a major source of nitrates in the atmosphere and a major source of fine particulate matter. As such, there have been increasing efforts to measure the atmospheric abundance of $\mathrm{NH}_{3}$ and its spatial and temporal variability. In this study, long-term measurements of $\mathrm{NH}_{3}$ derived from multiscale datasets are examined. These $\mathrm{NH}_{3}$ datasets include 16 years of total column measurements using Fourier transform infrared (FTIR) spectroscopy, 3 years of surface in situ measurements, and 10 years of total column measurements from the Infrared Atmospheric Sounding Interferometer (IASI). The datasets were used to quantify $\mathrm{NH}_{3}$ temporal variability over Toronto, Canada. The multiscale datasets were also compared to assess the representativeness of the FTIR measurements.

All three time series showed positive trends in $\mathrm{NH}_{3}$ over Toronto: $3.34 \pm 0.89 \% / y r$ from 2002 to 2018 in the FTIR columns, $8.88 \pm 5.08 \% / y r$ from 2013 to 2017 in the surface in situ data, and $8.38 \pm 1.54 \% / y r$ from 2008 to 2018 in the IASI columns. To assess the representative scale of the FTIR $\mathrm{NH}_{3}$ columns, correlations between the datasets were examined. The best correlation between FTIR and IASI was obtained with coincidence criteria of $\leq 25 \mathrm{~km}$ and $\leq 20 \mathrm{~min}$, with $r=0.73$ and a slope of $1.14 \pm 0.06$. Additionally, FTIR column and in situ measurements were standardized and correlated. Comparison of $24 \mathrm{~d}$ averages and monthly averages resulted in correlation coefficients of $r=0.72$ and $r=0.75$, respectively, although correlation without averaging to reduce high-frequency variability led to a poorer correlation, with $r=0.39$.
\end{abstract}

The GEOS-Chem model, run at $2^{\circ} \times 2.5^{\circ}$ resolution, was compared to FTIR and IASI to assess model performance and investigate the correlation of observational data and model output, both with local column measurements (FTIR) and measurements on a regional scale (IASI). Comparisons on a regional scale (a domain spanning 35 to $53^{\circ} \mathrm{N}$ and 93.75 to $63.75^{\circ} \mathrm{W}$ ) resulted in $r=0.57$ and thus a coefficient of determination, which is indicative of the predictive capacity of the model, of $r^{2}=0.33$, but comparing a single model grid point against the FTIR resulted in a poorer correlation, with $r^{2}=0.13$, indicating that a finer spatial resolution is needed for modeling $\mathrm{NH}_{3}$.

\section{Introduction}

Ammonia $\left(\mathrm{NH}_{3}\right)$ in the atmosphere plays an important role in the formation of nitrates and ammonium salts, is a major pollutant, and is known to be involved in numerous biochemical exchanges affecting all ecosystems (Erisman et al., 2008; $\mathrm{Hu}$ et al., 2014). As one of the main sources of reactive nitrogen in the atmosphere, $\mathrm{NH}_{3}$ is also associated with acidification and eutrophication of soils and surface waters, which can negatively affect biodiversity (Vitousek et al., 1997; Krupa, 2003; Bobbink et al., 2010). Furthermore, $\mathrm{NH}_{3}$ reacts with nitric acid and sulfuric acid to form ammonium salts, which are known to account for a large fraction of inorganic particulate matter (Schaap et al., 2004; Schiferl et al., 2014; Pozzer et al., 2017) and are thought to contribute to smog and haze (Liu et al., 2019; Wielgosiński and Czerwińska, 2020). Understanding how particulate matter forms is helpful in addressing air quality concerns (Schiferl et al., 2014), as particulate matter, especially that smaller than $2.5 \mu \mathrm{m}\left(\mathrm{PM}_{2.5}\right)$, 
poses serious health hazards affecting life expectancy in the United States (Pope et al., 2009) and globally (Giannadaki et al., 2014).

Due to the negative impacts $\mathrm{NH}_{3}$ can have on public health and the environment, $\mathrm{NH}_{3}$ emissions are regulated in some parts of the world (e.g., the 1999 Gothenburg Protocol to Abate Acidification, Eutrophication and Groundlevel Ozone). However, global $\mathrm{NH}_{3}$ emissions are increasing (Warner et al., 2016; Lachatre et al., 2019), and this has been attributed to increases in agricultural livestock numbers and increased nitrogen fertilizer usage (Warner et al., 2016). In addition, as the world population continues to grow and the demand for food rises, $\mathrm{NH}_{3}$ emissions are expected to further increase (van Vuuren et al., 2011). Observations show increasing an abundance of atmospheric $\mathrm{NH}_{3}$, particularly in the eastern United States, where trends as high as $12 \%$ annually were observed (Yu et al., 2018). Yu et al. (2018) concluded that the increase in $\mathrm{NH}_{3}$ abundance was in part due to decreasing $\mathrm{SO}_{2}$ and $\mathrm{NO}_{x}\left(\mathrm{NO}+\mathrm{NO}_{2}\right)$, owing to more stringent emissions regulations. $\mathrm{SO}_{2}$ and $\mathrm{NO}_{x}$ are precursors to acidic species (sulfuric and nitric acid, respectively) that react with $\mathrm{NH}_{3}$, and thus their abundances in the atmosphere determine the amount of $\mathrm{NH}_{3}$ that stays in the gaseous phase.

Atmospheric $\mathrm{NH}_{3}$ is rapidly removed by wet and dry deposition as well as by heterogeneous reactions with acids in the atmosphere, and thus it has a relatively short lifetime ranging from a few hours to a few days (Galloway et al., 2003; Dammers et al., 2019). $\mathrm{NH}_{3}$ lifetime may be longer for certain cases, such as biomass burning emissions that inject $\mathrm{NH}_{3}$ into the free troposphere (Höpfner et al., 2016), attenuating depositional and chemical losses, although physical and chemical mechanisms that lead to the transport of $\mathrm{NH}_{3}$ in biomass burning plumes over long distances remain uncertain (Lutsch et al., 2016, 2019). Dependence of $\mathrm{PM}_{2.5}$ formation on $\mathrm{NH}_{3}$ over urban areas also remains uncertain, and atmospheric chemical transport models have difficulty simulating $\mathrm{NH}_{3}$ and $\mathrm{PM}_{2.5}$ (e.g., Van Damme et al., 2014b; Fortems-Cheiney et al., 2016; Schiferl et al., 2016; Viatte et al., 2020).

Modeled $\mathrm{NH}_{3}$ can be used to supplement observations (Liu et al., 2017). However, ground-level $\mathrm{NH}_{3}$ abundances are poorly modeled, due to coarse model resolution, uncertain emissions inventories, and the simplification of chemistry schemes (Liu et al., 2017). Additionally, long-term trend analyses using models have been sparse (Yu et al., 2018). Representative measurements of $\mathrm{NH}_{3}$ on both local and regional scales, as well as their spatiotemporal variabilities, are needed to better understand and model $\mathrm{NH}_{3}$ and $\mathrm{PM}_{2.5}$ formation (Viatte et al., 2020).

Toronto is the most populous city in Canada, and $\mathrm{NH}_{3}$, along with other pollutants, is monitored by several instruments. In particular, the Fourier transform infrared (FTIR) spectrometer situated at the University of Toronto Atmospheric Observatory (TAO) has been making regular measurements since 2002. It is located in downtown Toronto, where local point sources (i.e., vehicle emissions) and nearby agricultural emissions, are major sources of $\mathrm{NH}_{3}$ (Zbieranowski and Aherne, 2012; Hu et al., 2014; Wentworth et al., 2014). Toronto is also regularly affected by biomass burning plumes transported from the USA and other regions of Canada (Griffin et al., 2013; Whaley et al., 2015; Lutsch et al., 2016, 2020). As such, the time series of total column $\mathrm{NH}_{3}$ measured at TAO exhibits long-term trends and pollution episodes. Toronto also has in situ (surface) measurements of $\mathrm{NH}_{3}$ (Hu et al., 2014), made by Environment and Climate Change Canada. A study by Hu et al. (2014) investigating $\mathrm{NH}_{3}$ in downtown Toronto has shown that greenery within the city, where chemical fertilizers are commonly used, is an important source of $\mathrm{NH}_{3}$ when temperatures are above freezing and that potential sources at temperatures below freezing have yet to be investigated. Additionally, recent studies have shown the increased capacity for satellitebased instruments to measure spatial and temporal distributions of $\mathrm{NH}_{3}$ total columns at global (Van Damme et al., 2014a; Warner et al., 2016; Shephard et al., 2020), regional (Van Damme et al., 2014b; Warner et al., 2017; Viatte et al., 2020), and point-source scales (Van Damme et al., 2018; Clarisse et al., 2019a; Dammers et al., 2019).

In this study, $\mathrm{NH}_{3}$ variability over Toronto is investigated using ground-based FTIR data, in situ measurements, and satellite-based observations from the Infrared Atmospheric Sounding Interferometer (IASI). This study is a part of the AmmonAQ project, which investigates the role of $\mathrm{NH}_{3}$ in air quality in urban areas. Trends in the $\mathrm{NH}_{3}$ time series and their statistical significance are determined, and the GEOS-Chem model is also used to supplement and compare to observations. Additionally, correlations between FTIR and IASI, FTIR and in situ, in situ and IASI, FTIR and model data, and IASI and model data on a regional scale are analyzed to assess the representativeness of the FTIR $\mathrm{NH}_{3}$ measurements.

The paper is organized as follows: Section 2 describes the FTIR retrieval methodology, the in situ and satellite data, the GEOS-Chem model, and the analysis methodologies. Section 3 presents the trend analysis of the FTIR, in situ, and IASI measurements, the results of the correlation studies, and an analysis of the representativeness of the FTIR $\mathrm{NH}_{3}$. Section 4 presents the evaluation of the GEOS-Chem model, and conclusions are provided in Sect. 5 .

\section{Datasets and methods}

\subsection{FTIR measurements}

Ground-based $\mathrm{NH}_{3}$ total columns used in this study were retrieved from infrared solar absorption spectra recorded using an ABB Bomem DA8 FTIR spectrometer situated at the University of Toronto Atmospheric Observatory in downtown Toronto, Ontario, Canada ( $43.66^{\circ} \mathrm{N}, 79.40^{\circ} \mathrm{W} ; 174 \mathrm{~m}$ a.s.1.). This instrument has been making measurements since mid- 
2002, and trace gas measurements are contributed to the Network for Detection of Atmospheric Composition Change (NDACC; http://www.ndaccdemo.org/, last access: 2 February 2021) (De Mazière et al., 2018). The DA8 has a maximum optical path difference of $250 \mathrm{~cm}$, with a maximum resolution of $0.004 \mathrm{~cm}^{-1}$, and is equipped with a $\mathrm{KBr}(700-$ $4300 \mathrm{~cm}^{-1}$ ) beam splitter. While the FTIR is equipped with both $\mathrm{InSb}$ and $\mathrm{HgCdTe}$ (MCT) detectors, $\mathrm{NH}_{3}$ profiles were retrieved using the $\mathrm{MCT}$ detector, which is responsive from $500-5000 \mathrm{~cm}^{-1}$. The DA8 is coupled to an active sun tracker, which was manufactured by Aim Controls. The tracker is driven by two Shinano stepper motors on elevation and azimuth axes. The active tracking was provided by four photodiodes from 2002-2014. This was upgraded to a camera and solar-disk-fitting system in 2014 (Franklin, 2015). Detailed specifications of the system can be found in Wiacek et al. (2007). Due to the nature of solar-pointing FTIR spectroscopy, the measurements are limited to sunny days, resulting in gaps in the time series. Measurements are typically made on $100-150 \mathrm{~d}$ per year.

The FTIR at TAO uses six filters recommended by the NDACC Infrared Working Group (IRWG) and measures spectra through each filter in sequence. $\mathrm{NH}_{3}$ profiles were retrieved using two microwindows in the 930.32$931.32 \mathrm{~cm}^{-1}$ and $966.97-967.675 \mathrm{~cm}^{-1}$ spectral regions. Interfering species include $\mathrm{H}_{2} \mathrm{O}, \mathrm{O}_{3}, \mathrm{CO}_{2}, \mathrm{~N}_{2} \mathrm{O}$, and $\mathrm{HNO}_{3}$. The solar absorption spectra recorded by the DA8 were processed using the SFIT4 retrieval algorithm (https://wiki.ucar. edu/display/sfit4/, last access: 1 November 2020). SFIT4 uses the optimal estimation method (OEM) (Rodgers, 2000) and works by iteratively adjusting the target species volume mixing ratio (VMR) profile until the difference between the calculated spectrum and the measured spectrum and the difference between the retrieved state vector and the a priori profile is minimized. The calculated spectra use spectroscopic parameters from HITRAN 2008 (Rothman et al., 2009) and atmospheric information (temperature and pressure profiles for any particular day) provided by the US National Centers for Environmental Prediction (NCEP). A priori VMR profiles were based on the a priori profile used at the NDACC site in Bremen (Dammers et al., 2015), which was obtained from balloon-based measurements (Toon et al., 1999). The $\mathrm{NH}_{3}$ retrieval methodology used at TAO is described in detail in Lutsch et al. (2016).

Uncertainties in the retrievals include measurement noise and forward model errors. Smoothing errors that arise due to the discretized vertical resolution were not included, to conform to NDACC standard practice. Measurement noise error includes errors due to uncertainties in instrument line shape, interfering species, and wavelength shifts. Uncertainties in line intensity and line widths were calculated based on HITRAN 2008 errors. Error analysis was performed on all retrievals (following Rodgers, 2000); the resulting errors were grouped into random and systematic uncertainties and added in quadrature. The resulting mean uncertainties aver- aged over the entire time series were $12.9 \%$ and $11.8 \%$ for random and systematic errors, respectively, for a total average error of $18.8 \%$ on the $\mathrm{NH}_{3}$ total columns. The mean degrees of freedom for signal (DOFSs) averaged over the 2002-2018 time series was 1.10 .

\subsection{In situ measurements}

To complement the FTIR total column $\mathrm{NH}_{3}$ measurements, the publicly available in situ data obtained by Environment and Climate Change Canada (ECCC) as a part of the National Air Pollution Surveillance Program (NAPS) were used (http://maps-cartes.ec.gc.ca/rnspa-naps/data.aspx, last access: 1 November 2020). The data span December 2013 to April 2017, with a sampling frequency of 1 in $3 \mathrm{~d}$. The sampling interval is $24 \mathrm{~h}$, from 00:00 to 24:00 local time, and samples were collected with a Met One SuperSASSPlus Sequential Speciation Sampler. The detection limit is $0.6 \mathrm{ppb}$ (Yao and Zhang, 2013). The integrated samples were brought back to the lab for analysis (Yao and Zhang, 2016). While errors are not reported in the dataset, the uncertainty is $10 \%$ when the $\mathrm{NH}_{3} \mathrm{VMR}$ is between 3 to $20 \mathrm{ppb}$ (Hu et al., 2014). The instrument is situated less than $500 \mathrm{~m}$ away from the FTIR, at $43.66^{\circ} \mathrm{N}, 79.40^{\circ} \mathrm{W}$ and $63 \mathrm{~m}$ a.s.1..

\subsection{IASI measurements}

IASI is a nadir-viewing FTIR spectrometer on board the MetOp-A, MetOp-B, and MetOp-C polar-orbiting satellites, operated by the European Organization for the Exploitation of Meteorological Satellites (EUMETSAT), which have been operational since 2006, 2012, and 2018, respectively. The MetOp A, B, and C satellites are in the same polar orbit. For all three satellites, IASI makes measurements at 09:30 and 21:30 mean local solar time for the descending and ascending orbits. IASI records spectra in the $645-2760 \mathrm{~cm}^{-1}$ spectral range at a resolution of $0.5 \mathrm{~cm}^{-1}$, with apodization. IASI can make off-nadir measurements of up to $48.3^{\circ}$ on either side of the track, leading to a swath of about $2200 \mathrm{~km}$. At nadir, the field of view is a $2 \times 2$ matrix of pixels, each with a $12 \mathrm{~km}$ diameter (Clerbaux et al., 2009).

The IASI $\mathrm{NH}_{3}$ total columns (IASI ANNI-NH3-v3) are retrieved using an artificial neural network retrieval algorithm, with ERA5 meteorological reanalysis input data (Van Damme et al., 2017; Franco et al., 2018). Due to this retrieval scheme, there are no averaging kernels nor vertical sensitivity information for the retrieved columns (Van Damme et al., 2014a). Details of the retrieval scheme and error analysis can be found in Whitburn et al. (2016) and Van Damme et al. (2017). IASI-A and IASI-B $\mathrm{NH}_{3}$ were combined and used in this study, as this allows for a longer time series and more data points for robust analysis. The retrieved columns of $\mathrm{NH}_{3}$ from both satellites have been shown to be consistent with each other (Clarisse et al., 2019b; Viatte et al., 2020). 


\subsection{GEOS-Chem}

The GEOS-Chem (v11-01) global chemical transport model (CTM) (http://geos-chem.org, last access: 1 November 2020) was used in this study to supplement and compare to observational data. The model was run at $2^{\circ} \times 2.5^{\circ}$ resolution (latitude $\times$ longitude) using MERRA2 (Modern-Era Retrospective analysis for Research and Applications, Version 2) meteorological fields (Molod et al., 2015) and the EDGAR v4.2 emissions database (Janssens-Maenhout et al., 2019) for anthropogenic emissions. For $\mathrm{NH}_{3}$, EDGAR v4.2 and GEIA were used as global inventories, with GEIA providing the natural source of $\mathrm{NH}_{3}$ (Bouwman et al., 1997; Olivier et al., 1998; Croft et al., 2016). The global inventories were replaced with the US EPA National Emission Inventory for 2011 (NEI11; https://www.epa.gov/air-emissions-inventories/ 2011-national-emissions-inventory-nei-data, last access: 1 November 2020) in the United States and by the Criteria Air Contaminants (CACs) from the National Pollutant Release Inventory in Canada (https://www.ec.gc.ca/inrp-npri/, last access: 1 November 2020). The NEI11 emissions were scaled between the years 2006-2013, whereas the CAC $\mathrm{NH}_{3}$ emissions used 2008 as the base year, with no scaling applied. The NEI11 emissions were hourly, whereas the CAC emissions were monthly. The GEOSChem model includes a detailed tropospheric oxidant chemistry and aerosol simulation (e.g., $\mathrm{H}_{2} \mathrm{SO}_{4}-\mathrm{HNO}_{3}-\mathrm{NH}_{3}$ simulation) (Park et al., 2004). For $\mathrm{SO}_{2}$ and $\mathrm{NO}$, which can lead to the formation of sulfates and nitrates that influence $\mathrm{NH}_{3}$ uptake to aerosols, the EDGAR and CAC (for Canada; https://www.ec.gc.ca/inrp-npri/, last access: 1 November 2020) inventories were used. $\mathrm{NH}_{3}$ gas-aerosol partitioning is calculated using the ISORROPIA II model (Fountoukis and Nenes, 2007). Chemistry and transport are calculated with 20 and $10 \mathrm{~min}$ time steps, respectively. The model was spun up for 1 year, and output was saved every hour from 2002 to 2018.

\subsection{TAO FTIR and IASI comparison}

To assess the representative spatial and temporal scale of TAO FTIR $\mathrm{NH}_{3}$ columns, the $\mathrm{NH}_{3}$ total column measurements around Toronto made by IASI were compared to TAO FTIR total columns and modeled $\mathrm{NH}_{3}$ columns (see Sect. 3.3). As $\mathrm{NH}_{3}$ shows high spatiotemporal variability, several definitions of coincident measurements were used in this study, with spatiotemporal criteria of varying strictness. As $\mathrm{NH}_{3}$ concentrations can vary significantly during the day, the temporal coincidence criterion was chosen to be $\leq 90 \mathrm{~min}$ (Dammers et al., 2016). In addition, values of $\leq 60,45,30$, and 20 min were also tested. For spatial coincidence criteria, $\leq 25$ (Dammers et al., 2016), 30, 50, and $100 \mathrm{~km}$ were tested. For each criterion, correlations (both $r$ and slope) were calculated. This analysis was used to eval- uate the spatial and temporal scales represented by the TAO FTIR $\mathrm{NH}_{3}$ columns.

\subsection{Trend analysis and identifying pollution events}

With 16 years of data, relatively long-term trends of TAO FTIR column time series can be examined. While a trend analysis simply using monthly averages is possible (Angelbratt et al., 2011), a more sophisticated method of fitting Fourier series of several orders was utilized in this study (Weatherhead et al., 1998). Bootstrap resampling was utilized to derive the confidence interval of the trends (Gardiner et al., 2008). A $Q$ value (the number of bootstrap resampling ensemble members generated for statistical analysis) of 5000 was used (Gardiner et al., 2008). An additional analysis to determine the number of years of measurements needed to give the derived trend statistical significance ( $2 \sigma$ confidence) was also conducted, following Weatherhead et al. (1998). This analysis takes into account the need for longer time series to identify trends in data that are autocorrelated (as are atmospheric observations). It should be noted that a major limitation of this analysis is that it assumes that data are collected at regular intervals, while TAO measurements are made at irregular intervals (due to the need for sunny conditions). For this reason, the confidence intervals derived from bootstrap resampling are a more robust method of error analysis, in the case of TAO data. However, as pointed out by Weatherhead et al. (1998), failing to take into account the autocorrelation of the noise can lead to underestimations of actual uncertainty, and for this reason, both bootstrap resampling and the Weatherhead method were used in this study. These techniques were combined to assess the intra- and inter-annual trends of $\mathrm{NH}_{3}$ derived from TAO measurements, including a linear trend of the $\mathrm{NH}_{3}$ total column along with its uncertainties and statistical significance. This analysis was also applied to the NAPS in situ and IASI data.

The Fourier fit was used to identify $\mathrm{NH}_{3}$ enhancements, following Zellweger et al. (2009). This analysis is done by taking the negative residuals of the fit (i.e., measured values smaller than fitted values), mirroring them, and calculating the standard deviation $(\sigma)$ of the mirrored residuals. Any measurements that are $2 \sigma$ above the fit are considered enhancements. This analysis reduces biases in the spread due to enhancements by mirroring the negative residuals.

In this study, Fourier series of order 3 were utilized for all analyses. An analysis was done by comparing Fourier series fits of order 1 to 7 and checking for overfitting by running the residuals of the fit through a normality test (the KolmogorovSmirnov test). While overfitting was not observed at higher orders, higher orders did not give more statistically significant trends, so order 3 was chosen. 


\section{Results and discussion}

\subsection{FTIR measurements}

The TAO FTIR total column time series of $\mathrm{NH}_{3}$ is shown in Fig. 1. The purple points indicate enhancements, and the trends (with and without outliers) are shown as red and cyan lines, respectively. The trend from 2002 to 2018 was found to be $3.34 \pm 0.89 \% / \mathrm{yr}$ and $2.23 \pm 0.62 \% / \mathrm{yr}(2 \sigma$ confidence interval from bootstrap resampling), with and without outliers, respectively (see Table 2). The number of years of measurements needed for the trend to be statistically $(2 \sigma)$ significant was found to be 33.8 years and 29.3 years, with and without enhancement events, respectively. Due to the irregular FTIR measurement intervals, these numbers may not represent the true significance of the trends and should be regarded as best estimates of the significance of the observed trend. The lower magnitude of the upward trend in the analysis without enhancement values indicates that the intra-annual variability of $\mathrm{NH}_{3}$ is increasing. This is also evident when comparing the mean total column and standard deviations from, for example, the periods 2002-2005 and 2015-2018. In the former period, the mean $\mathrm{NH}_{3}$ total column and standard deviation $(1 \sigma)$ were $5.94 \pm 5.14 \times 10^{15}$ molecules $/ \mathrm{cm}^{2}$, while in the latter time frame, they were $8.13 \pm 7.88 \times 10^{15}$ molecules $/ \mathrm{cm}^{2}$. The observed trend with the FTIR is comparable to a study by Warner et al. (2017), who observed an increasing $\mathrm{NH}_{3}$ trend of $2.61 \% / \mathrm{yr}$ over the United States from 2002 to 2016 using data from the Atmospheric Infrared Sounder (AIRS) satellite-based instrument.

Figure 2 shows the annual cycle of the FTIR $\mathrm{NH}_{3}$ total columns, color-coded by year, along with the monthly averages and $\pm 2 \sigma$. FTIR $\mathrm{NH}_{3}$ columns have a maximum in May with a monthly total column average of $13.14 \pm 11.69 \times 10^{15}$ molecules $/ \mathrm{cm}^{2}$, largely due to agricultural and soil emissions increasing in spring and summer (Hu et al., 2014; Dammers et al., 2016), and a minimum in January with a monthly total column average of $2.11 \pm 1.81 \times 10^{15}$ molecules $/ \mathrm{cm}^{2}$. The lower $\mathrm{NH}_{3}$ columns during winter months may be due to lower temperatures favoring the formation of $\mathrm{NH}_{4} \mathrm{NO}_{3}(\mathrm{Li}$ et al., 2014). The seasonal cycle observed with the FTIR is consistent with findings by Van Damme et al. (2015b), who observed maximum $\mathrm{NH}_{3}$ columns over the central United States during March-April-May (MAM). The mean $\mathrm{NH}_{3}$ total column across the entire FTIR time series was $7.53 \pm 7.10 \times 10^{15}$ molecules $/ \mathrm{cm}^{2}$. These values are higher than remote areas, such as Eureka (located at $80.05^{\circ} \mathrm{N}$, $86.42^{\circ} \mathrm{W}$ ), where the highest monthly average was $0.279 \times$ $10^{15}$ molecules $/ \mathrm{cm}^{2}$, in July (Lutsch et al., 2016). However, the TAO FTIR $\mathrm{NH}_{3}$ total columns are far below values observed by the FTIR in Bremen (located at $53.10^{\circ} \mathrm{N}, 8.85^{\circ} \mathrm{E}$ ), which saw values in the range of $\sim 100 \times 10^{15}$ molecules $/ \mathrm{cm}^{2}$ (Dammers et al., 2016). Monthly mean $\mathrm{NH}_{3}$ columns are listed in Table 1.
Table 1. Monthly mean ( $1 \sigma$ in parenthesis) $\mathrm{NH}_{3}$ total columns of the TAO FTIR (2002-2018).

\begin{tabular}{lr}
\hline Month & $\left.\begin{array}{r}\text { Mean columns } \\
\left(\times 10^{15} \text { molecules/cm }\right.\end{array}\right)$ \\
\hline January & $2.11(1.81)$ \\
February & $3.84(3.68)$ \\
March & $4.05(4.19)$ \\
April & $6.48(6.52)$ \\
May & $13.14(11.69)$ \\
June & $7.17(5.54)$ \\
July & $8.27(6.19)$ \\
August & $6.89(4.89)$ \\
September & $7.81(6.91)$ \\
October & $5.81(4.30)$ \\
November & $5.36(5.28)$ \\
December & $2.59(1.81)$ \\
\hline Overall mean & $7.53(7.10)$ \\
\hline
\end{tabular}

\subsection{NAPS measurements}

The NAPS in situ $\mathrm{NH}_{3}$ time series is shown in Fig. 3. The purple points indicate enhancements, and trend lines with and without these outliers are shown as the red and cyan lines, respectively. The trend line was found to have a slope of $8.88 \pm 5.08 \% / \mathrm{yr}$ and $6.40 \pm 4.37 \% / \mathrm{yr}$ ( $2 \sigma$ confidence interval from bootstrap resampling), with and without outliers, respectively. The number of years needed for this trend to be $2 \sigma$ significant was 8.4 years for both. Since NAPS data have very regular measurement intervals (once every $3 \mathrm{~d}$ ), they are well suited for this trend significance analysis. Given that NAPS data only span 3 years and 5 months and given that 8.4 years of measurements are needed for $2 \sigma$ confidence in the observed trend, it is uncertain if the increase in $\mathrm{NH}_{3}$ levels is a definitive trend. For comparison, analysis of TAO FTIR $\mathrm{NH}_{3}$ total columns during the same time period resulted in trends of $9.31 \pm 5.73 \% / \mathrm{yr}$ and $7.42 \pm 4.48 \% / \mathrm{yr}$, with and without outliers, respectively.

The in situ $\mathrm{NH}_{3}$ VMRs were compared to the TAO FTIR columns by standardizing both measurements, following Eq. (1) of Viatte et al. (2020):

$X_{\text {standardized }}^{i}=\frac{X_{i}-\mu_{X}}{\sigma_{X}}$,

where $X$ is the dataset, indexed by $i, \mu$ is the mean, and $\sigma$ is the standard deviation of the dataset. The standardized dataset is centered around zero and normalized by the standard deviation of the measurements. As the standardized dataset is unitless, it allows for comparison between different measurements in different units. In this study, the TAO FTIR $\mathrm{NH}_{3}$ total columns were used because the DOFS for the retrieval was around 1 (mean DOFS of the entire time series was 1.10), meaning there is only about one piece of vertical information in these measurements. 


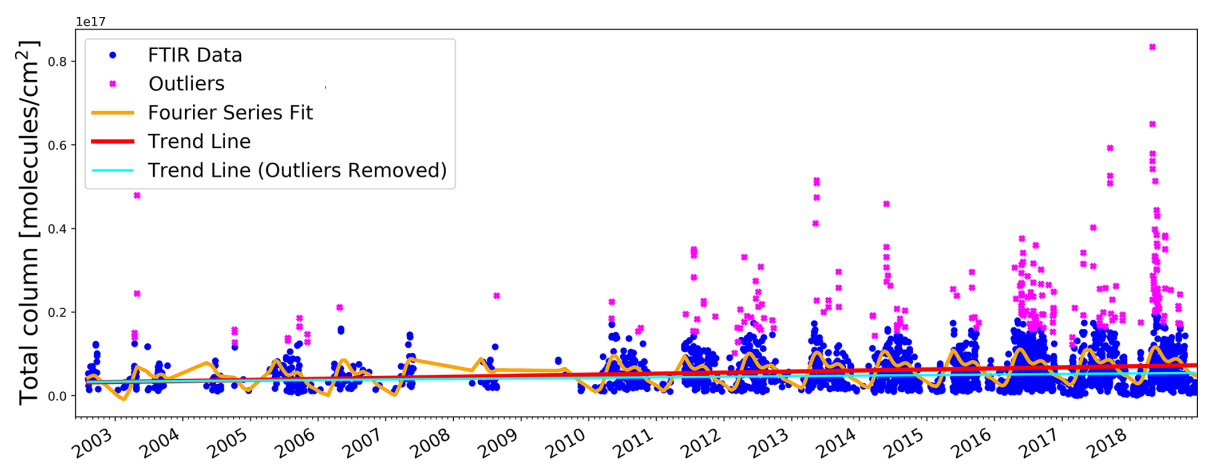

Figure 1. Time series of TAO FTIR $\mathrm{NH}_{3}$ total columns from 2002 to 2018 with third-order Fourier series fit and linear trends.

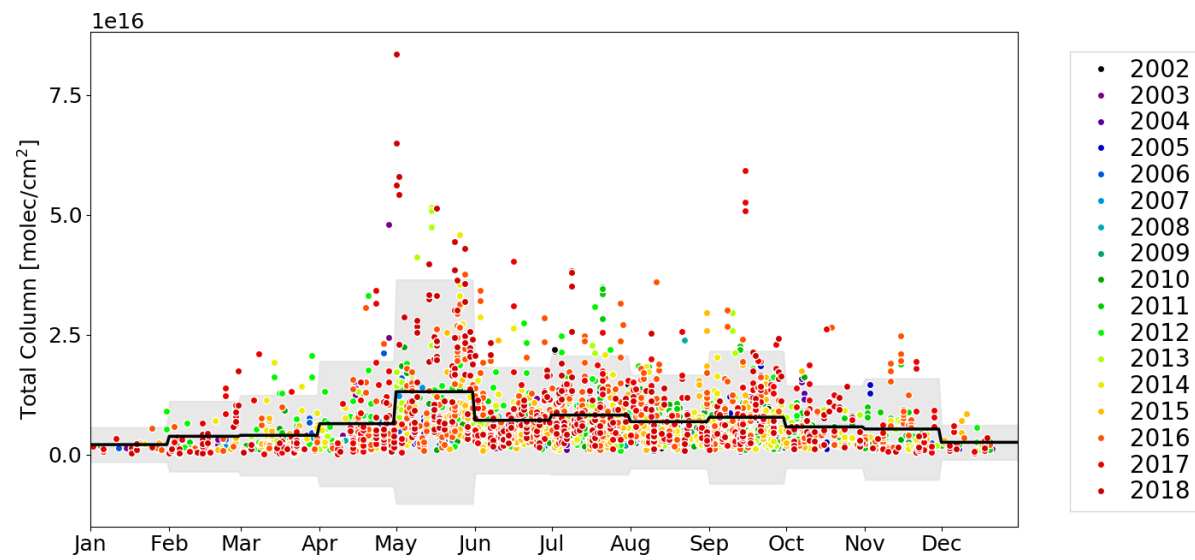

Figure 2. TAO FTIR $\mathrm{NH}_{3}$ total columns plotted from January to December for 2002 to 2018 . Monthly averages and $\pm 2 \sigma$ are indicated by the black line and shading, respectively.

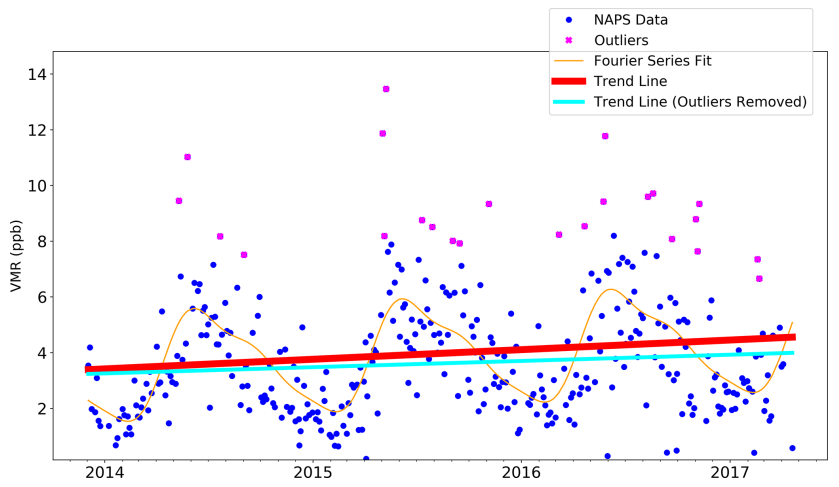

Figure 3. Time series of NAPS $\mathrm{NH}_{3}$ surface VMR from 2013 to 2017 with third-order Fourier series fit and linear trends.

Standardized FTIR and NAPS $\mathrm{NH}_{3}$ are plotted in Fig. $4 \mathrm{a}$. Monthly averages and monthly standard deviations are shown in Fig. 4b. The two measurements show similar seasonal cycles, with a maximum in May and a minimum in December and January. There is a smaller secondary peak in November for both measurements. This may be due to lateseason fertilizer application and cover crop growth. The Min- istry of Agriculture, Food and Rural Affairs of Ontario recommends applying fertilizer in spring and fall (Munroe et al., 2018). Correlation between the two datasets can be seen in Fig. 5a, where each NAPS measurement is plotted against the average of FTIR measurements on that day (if any measurements are available). This simple comparison does not show a strong correlation, with $r=0.51$ and slope $=0.501$. However, resampling the measurements by $15 \mathrm{~d}$ averages (Fig. 5b), $18 \mathrm{~d}$ averages (Fig. 5c), $24 \mathrm{~d}$ averages (Fig. 5d), and by monthly averages (Fig. 5e) shows much stronger correlations. Resampling to $15 \mathrm{~d}$ averages shows better correlation with $r=0.63$ and a larger slope $=0.707$. Averaging to every 18 and $24 \mathrm{~d}$ leads to $r=0.68$ and 0.72 , respectively. Monthly averages show the highest correlation with $r=0.75$ and a slope $=0.758$. This indicates that the FTIR and NAPS see similar low-frequency variabilities (period of 2 weeks or longer) in $\mathrm{NH}_{3}$.

It should be noted that a bias would be expected to be observed between the FTIR and NAPS data, as the FTIR can only make measurements during sunny conditions, while NAPS data are $24 \mathrm{~h}$ averages, made once every $3 \mathrm{~d}$. This means that NAPS data include observations made during nighttime and rainy conditions. This is noteworthy, as sur- 
Table 2. Comparison of $\mathrm{NH}_{3}$ trends and $2 \sigma$ confidence intervals observed in Toronto. All trends are in \%/year.

\begin{tabular}{lcccc}
\hline Dataset & Time frame & Trends & Trends without outliers & $\begin{array}{c}\text { TAO trends during the same time frame } \\
\text { as either the NAPS or IASI data }\end{array}$ \\
\hline TAO & $2002-2018$ & $3.34 \pm 0.89$ & $2.23 \pm 0.62$ & - \\
NAPS & $2013-2017$ & $8.88 \pm 5.08$ & $6.40 \pm 4.37$ & $9.31 \pm 5.73$ \\
IASI & $2008-2018$ & $8.38 \pm 1.54$ & - & $4.02 \pm 1.42$ \\
\hline
\end{tabular}

(a)

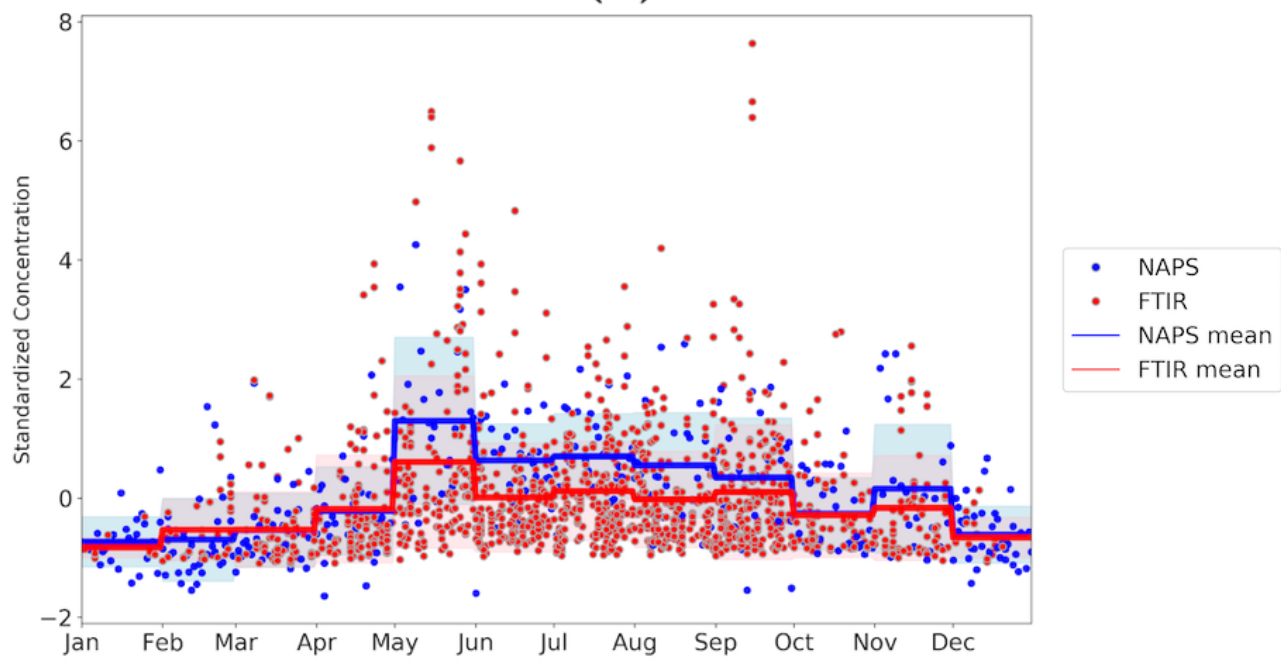

(b)

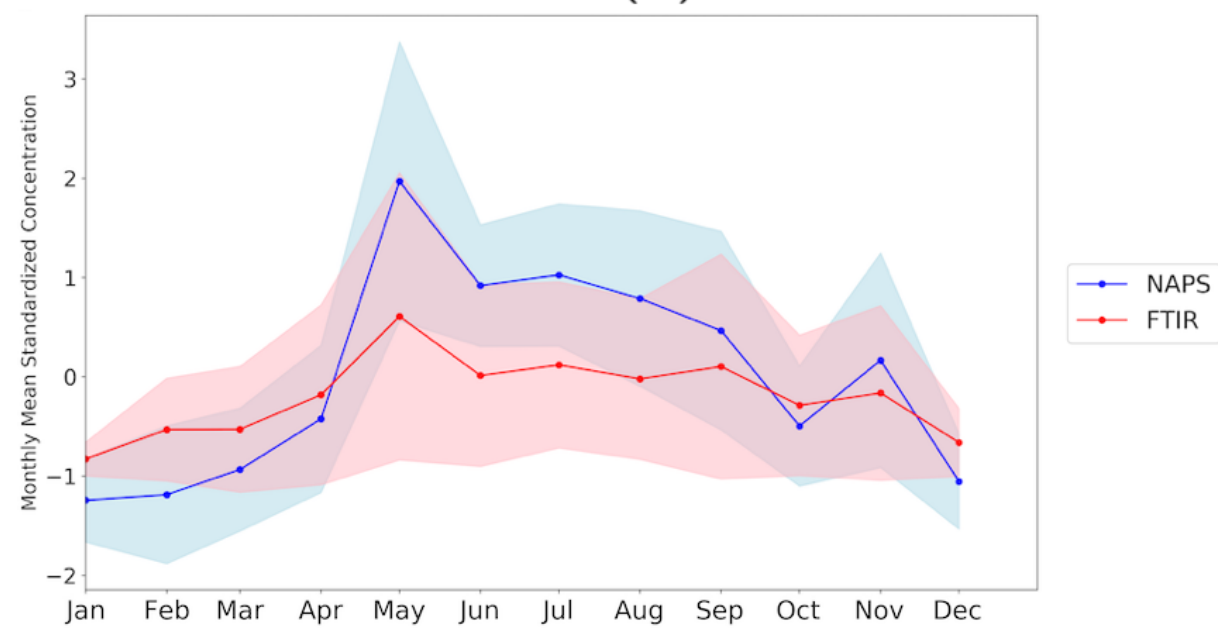

Figure 4. (a) Standardized FTIR total column and NAPS surface VMR of $\mathrm{NH}_{3}$ plotted from January to December. Monthly averages and $\pm 1 \sigma$ are indicated by the red and blue lines and shading for the FTIR and NAPS, respectively. (b) The standardized FTIR NH 3 total column (red) and NAPS surface $\mathrm{NH}_{3}$ VMR (blue) monthly average lines with their respective $\pm 1 \sigma$ (shading).

face $\mathrm{NH}_{3}$ concentrations may be affected by diurnal variability in the planetary boundary layer height. Temperature may also affect $\mathrm{NH}_{3}$ enhancement events. When coincident datasets were analyzed for enhancements, $3 \mathrm{~d}$ showed simultaneous enhancements (25 May 2014, 23 May 2016, 26 May 2016). On all $3 \mathrm{~d}$, the daily average temperature (measured by the TAO weather station) was higher than the corresponding monthly average: $19.3 \pm 2.8^{\circ} \mathrm{C}$ (uncertainties indicate 1 standard deviation) on 25 May 2014 vs. May 2014 monthly mean of $13.8^{\circ} \mathrm{C}$ and $19.6 \pm 3.4$ and $21.2 \pm 2.8^{\circ} \mathrm{C}$ for 23 May and 26 May 2016, respectively, vs. the May 2016 monthly mean of $14.1^{\circ} \mathrm{C}$. This is unsurprising, given that 
(a)

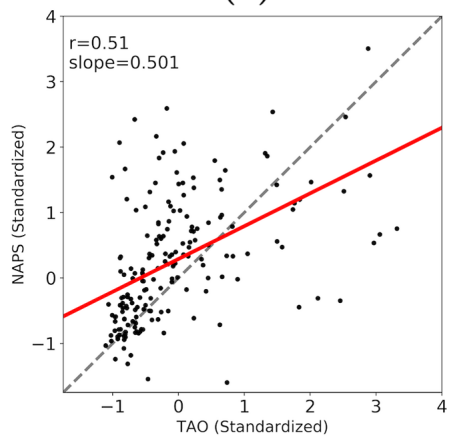

(b)

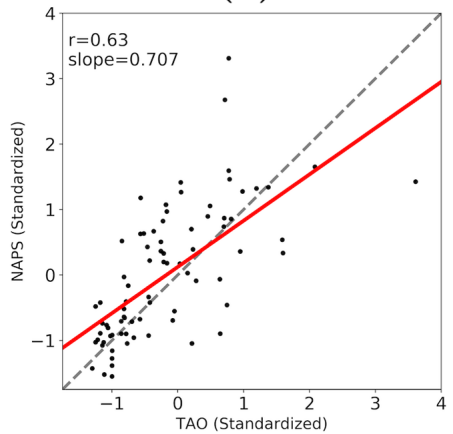

(d)

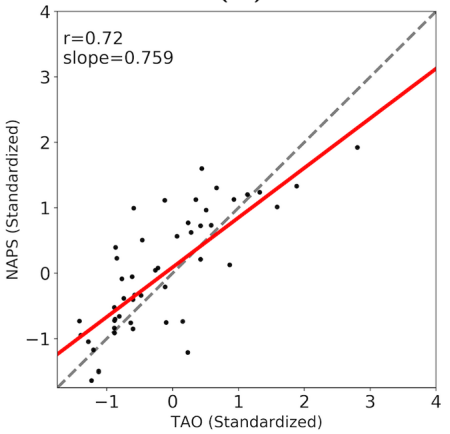

(c)

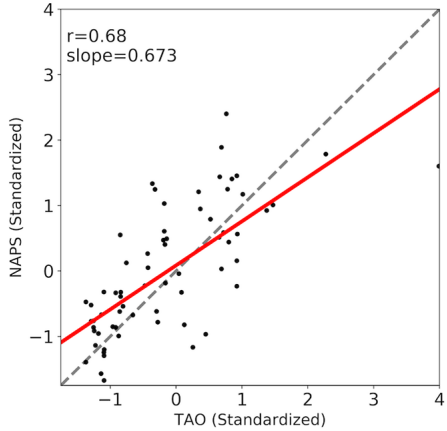

(e)

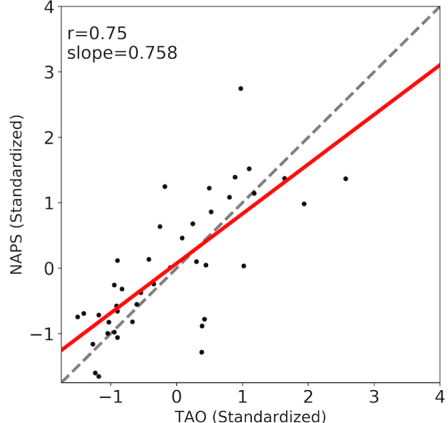

Figure 5. Standardized NAPS $\mathrm{NH}_{3}$ surface VMR plotted against standardized FTIR $\mathrm{NH}_{3}$ total column. (a) The raw comparison, where the closest daily average FTIR measurement is plotted for each NAPS observation if there are any within $72 \mathrm{~h}$. FTIR and in situ resampled to (b) $15 \mathrm{~d}$, (c) $18 \mathrm{~d}$, (d) $24 \mathrm{~d}$, and (e) monthly averages. The dashed lines indicate slope $=1$, and the red lines indicate the fit to the data.

increased $\mathrm{NH}_{3}$ is correlated with higher temperatures (e.g., Meng et al., 2011). Since the FTIR can only make measurements on sunny days, its measurements may be biased high compared to NAPS, which makes measurements regardless of weather.

\subsection{IASI measurements}

The time series of IASI $\mathrm{NH}_{3}$ total columns (2008 to 2018) within $50 \mathrm{~km}$ of TAO is shown in Fig. 6. The trend of these IASI measurements is $8.38 \pm 1.43 \% / \mathrm{yr}$, where the error indicates the $2 \sigma$ confidence interval obtained by bootstrap resampling analysis. The Weatherhead et al. (1998) method for finding the statistical significance of this trend was not utilized here, as the analysis requires calculating the autocorrelation of data, which is not possible given the spatially scattered dataset. For comparison, the TAO FTIR trend over the same period is $4.02 \pm 1.42 \% / \mathrm{yr}$.

The correlations between IASI and TAO FTIR $\mathrm{NH}_{3}$ columns for the various coincidence criteria listed in Sect. 2.3 are shown in Table 3, along with the slopes, mean relative difference (MRDs), and total number of data points. The MRD was calculated by subtracting the TAO FTIR column from the IASI column, then dividing by the TAO FTIR column (Dammers et al., 2016). To maximize the number of coincident data points, no significant data filtering (e.g., fil-

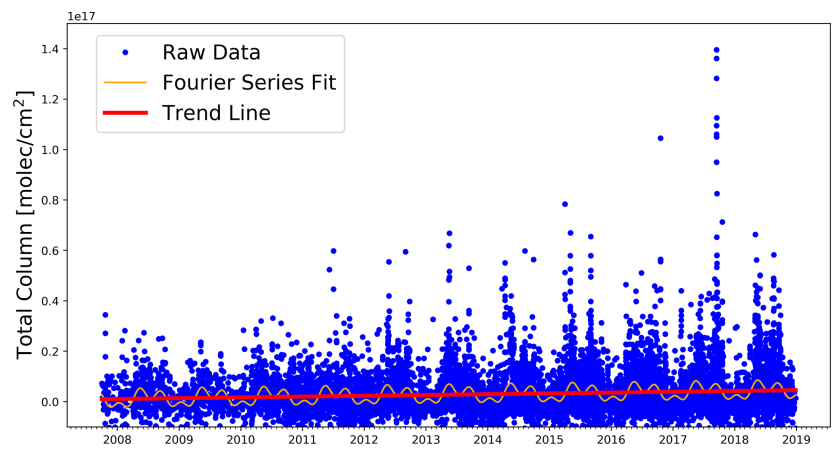

Figure 6. Time series of IASI $\mathrm{NH}_{3}$ total columns measured within $50 \mathrm{~km}$ of TAO. The third-order Fourier series fit and the trend line are shown in orange and red, respectively.

tering by relative errors) was performed. The criteria used by Dammers et al. (2016) (90 min, $25 \mathrm{~km}$ ) show a correlation with $r=0.65$ and slope $=0.88$ in this study, comparable to $r=0.79$ and slope $=0.84$ reported by Dammers et al. (2016). The MRD was $-45.5 \pm 207.2 \%$ for this study, consistent with $-46.0 \pm 47.0 \%$ calculated by Dammers et al. (2016) for TAO FTIR data. The larger standard deviation of the MRD is most likely because the data used here were not filtered by relative errors. The best correlation was achieved when using measurements made within $20 \mathrm{~min}$ and within 
$25 \mathrm{~km}$ of each other, which resulted in $r=0.73$ and a slope of 1.14. Coincidence criteria of $20 \mathrm{~min}$ and $50 \mathrm{~km}$ gave $r=0.68$ and slope $=1.06$. Criteria of $45 \mathrm{~min}$ and $50 \mathrm{~km}$ also show a correlation comparable to the $90 \mathrm{~min}, 25 \mathrm{~km}$ criteria, with $r=0.64$ and slope $=0.92$. This suggests that TAO FTIR is a good indicator of $\mathrm{NH}_{3}$ concentrations on a city-wide scale $(\sim 50 \mathrm{~km})$. This is also evident when looking at the correlation between TAO FTIR columns vs. daily averaged IASI measurements within $50 \mathrm{~km}$, which had $r=0.69$, although the slope was smaller, at 0.82 . The better correlations seen with the stricter temporal criteria suggest that $\mathrm{NH}_{3}$ near Toronto exhibits high-frequency variability. The values obtained in this study are also comparable to recent findings by Tournadre et al. (2020), who compared $\mathrm{NH}_{3}$ columns from an FTIR stationed in Paris to IASI $\mathrm{NH}_{3}$ columns. With a $15 \mathrm{~km}$ and $30 \mathrm{~min}$ coincidence criteria, the FTIR in Paris showed a correlation of $r=0.79$ and slope $=0.73$. The same study also found that the FTIR in Paris is capable of providing information about $\mathrm{NH}_{3}$ variability at a "regional" scale $(\sim 120 \mathrm{~km})$ (Tournadre et al., 2020). Although not quantified in this study, the line-of-sight through the atmosphere (which changes throughout the day) may also affect the representative scale of ground-based solarpointing FTIR observations. Additionally, the number of observations is relatively large for each criterion (e.g., $N=923$ for $90 \mathrm{~min}, 25 \mathrm{~km}$, while $N=679$ for $45 \mathrm{~min}, 50 \mathrm{~km}$ ), suggesting that the differences in correlation are not simply due to the differences in the number of data points. The correlation plots for $20 \mathrm{~min} / 25 \mathrm{~km}, 90 \mathrm{~min} / 25 \mathrm{~km}, 20 \mathrm{~min} / 50 \mathrm{~km}$, and $45 \mathrm{~min} / 50 \mathrm{~km}$ are shown in Fig. $7 \mathrm{a}, 7 \mathrm{~b}, 7 \mathrm{c}$, and $7 \mathrm{~d}$, respectively. It should be noted that the slope was calculated through a simple linear least-squares regression. For comparison, an additional analysis was done propagating measurement uncertainty using the unified least squares procedure outlined by York et al. (2004) and yielded similar results, with a smaller slope for all cases due to the larger relative uncertainty on IASI measurements $(\sim 68 \%$ for IASI compared to $\sim 19 \%$ for TAO FTIR).

IASI column and NAPS surface $\mathrm{NH}_{3}$ were also compared in this study by converting to standardized data (see Eq. 1). Comparing the monthly means resulted in $r=0.79$ and slope $=0.79$ when looking at IASI measurements made within $50 \mathrm{~km}$ of NAPS and $r=0.74$ and slope $=0.74$ for $30 \mathrm{~km}$. Without temporal averaging, no significant correlation was found $(r \leq 0.27)$ for any spatial coincidence criteria. This is in line with findings from Van Damme et al. (2015a), where significant correlation was found when comparing monthly averaged surface and IASI measurements. Van Damme et al. (2015a) report $r=0.28$ when comparing IASI with an ensemble of surface observations over Europe and $r$ as high as 0.81 and 0.71 for measurements made at Fyodorovskoye, Russia, and Monte Bondone, Italy, respectively. It should be noted that the comparisons in Van Damme et al. (2015a) were done by converting IASI $\mathrm{NH}_{3}$ columns to surface concentration by using the same model used in the retrieval process, as opposed to the standardized dataset approach used in this study.

\section{Comparison with GEOS-Chem}

The $\mathrm{NH}_{3}$ total column from the GEOS-Chem CTM model grid cell containing Toronto (grid center at $44^{\circ} \mathrm{N}, 80^{\circ} \mathrm{W}$ ) is shown in Fig. 8a, along with TAO FTIR data. The correlation was obtained by comparing the hourly model data for each FTIR observation. Comparison with the FTIR was done with and without smoothing the model data with the FTIR averaging kernel and a priori profile (Rodgers and Connor, 2003). As smoothing the model data only resulted in differences of less than $1 \%$, the discussion here will focus on the unsmoothed dataset to be consistent with the comparison with IASI. While GEOS-Chem is able to capture the seasonal cycle seen with the FTIR, the correlation is not strong, with $r=0.51$ and the coefficient of determination, $r^{2}$, at 0.26 (see Fig. 9a). The calculated slope was 1.16. Both of these values are without smoothing the model data. Smoothing the data resulted in $r^{2}=0.28$ and slope $=1.01$ It is likely that the model is too coarse (the $2^{\circ} \times 2.5^{\circ}$ grid box corresponds to approximately $220 \mathrm{~km} \times 200 \mathrm{~km}$ ), and the FTIR, while able to capture larger-scale variability in $\mathrm{NH}_{3}$ than in situ observations, is not sensitive to observations at spatial scales of $100 \mathrm{~km}$ or larger. Given the short lifetime of $\mathrm{NH}_{3}$, it is unsurprising to see large variability at these spatial scales.

For comparison with IASI, a larger domain was chosen to assess the correlation of the model and satellite observations at a larger regional scale. Model grids spanning 35 to $53^{\circ} \mathrm{N}$ and 93.75 to $63.75^{\circ} \mathrm{W}$ were used for the analysis, as these grids capture Toronto, the Great Lakes, and the Atlantic Ocean coastline. The spatial coincidence was calculated by binning the IASI data into the grids of GEOS-Chem, and temporal coincidence was determined by calculating the mean overpass time in the domain and averaging the model data between $1 \mathrm{~h}$ before and $1 \mathrm{~h}$ after the mean overpass time. The time series (both GEOS-Chem and IASI were averaged over the domain), and correlation plots are shown in Figs. $8 \mathrm{~b}$ and $9 \mathrm{~b}$, respectively. The correlation of GEOSChem against IASI is higher than GEOS-Chem against TAO FTIR, with $r^{2}=0.33$ (see Fig. 9b). Removing enhancement events from observational data led to poorer correlation with GEOS-Chem, with $r^{2}=0.22$ and $r^{2}=0.29$ for the FTIR and IASI, respectively (see Fig. 9c and 9d). This is comparable to findings by Schiferl et al. (2016), who observed IASI and GEOS-Chem correlations $(r)$ of $0.6-0.8$ in the United States Great Plains and the Midwest during the summer. The slope was 0.85 , meaning $\mathrm{NH}_{3}$ is overestimated in GEOS-Chem when compared to IASI at this scale. Comparing GEOSChem and IASI for one grid cell over Toronto (same cell as the one used for comparison with TAO FTIR) resulted in a lower correlation, at $r^{2}=0.13$. These results suggest GEOSChem is able to model $\mathrm{NH}_{3}$ on larger regional scales but a 
(a)

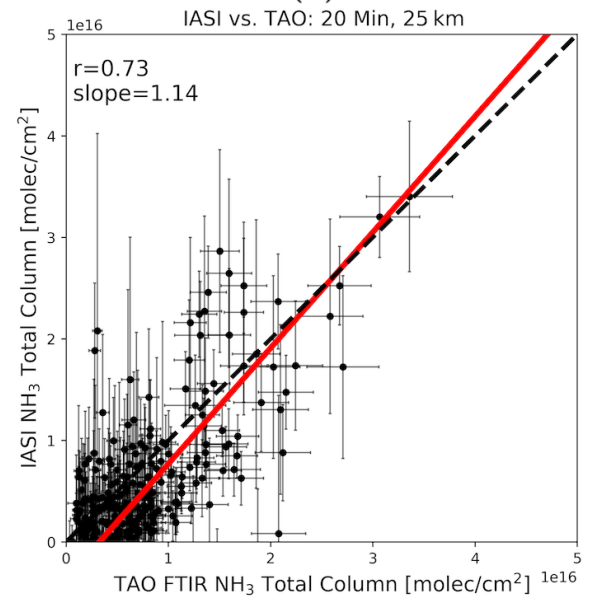

(c)

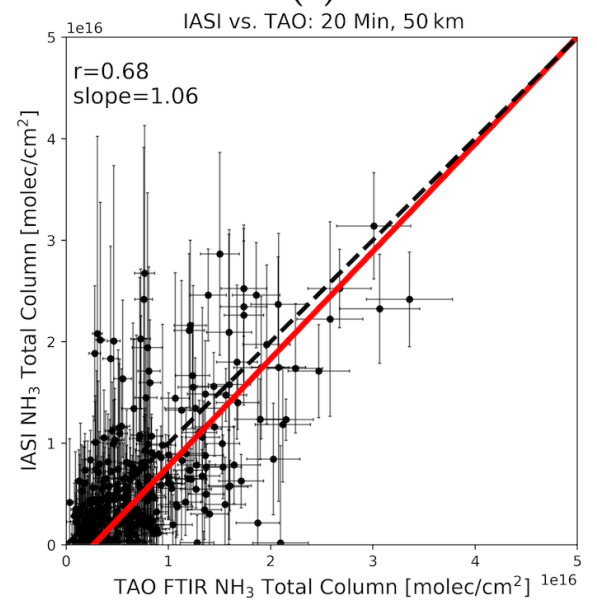

(b)

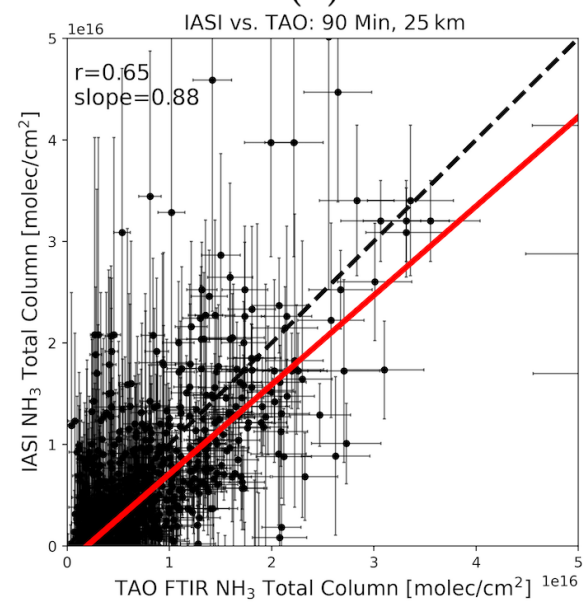

(d)

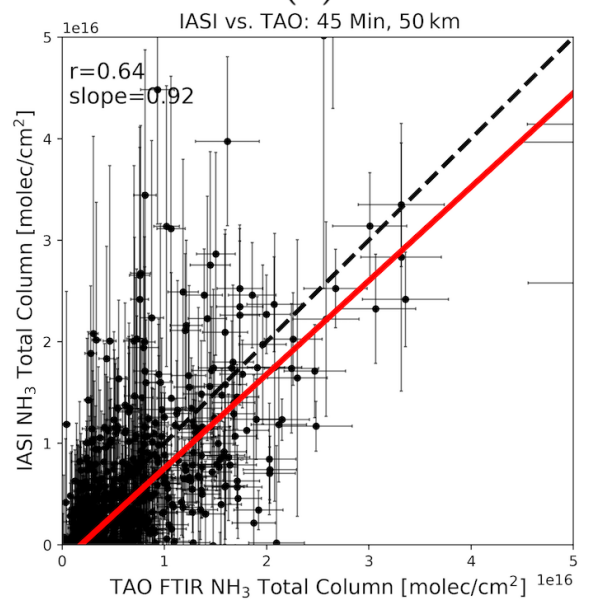

Figure 7. Correlation plots for IASI vs. TAO FTIR $\mathrm{NH}_{3}$ total columns, with coincidence criteria of (a) $20 \mathrm{~min}$ and $25 \mathrm{~km}$, (b) $90 \mathrm{~min}$ and $25 \mathrm{~km}$, (c) $20 \mathrm{~min}$ and $50 \mathrm{~km}$, and (d) $45 \mathrm{~min}$ and $50 \mathrm{~km}$. Data from 2008 to 2018 are plotted. Dashed lines indicate slope $=1$, while the red lines are the lines of best fit. Error bars are the reported observational uncertainties.

finer resolution is needed for better comparison with smaller regions. In addition, while the modeled $\mathrm{NH}_{3}$ was overestimated in comparison with IASI over a larger regional domain, the comparison for the single grid box over Toronto resulted in slope $=2.44$, meaning the model underestimated $\mathrm{NH}_{3}$ in this smaller region, which may indicate underestimation of local $\mathrm{NH}_{3}$ sources near Toronto in the model. This can be contrasted with recent findings by Van Damme et al. (2014b), who observed an overall underestimation of $\mathrm{NH}_{3}$ in the LOTOS-EUROS model over Europe when compared to IASI. In a 4-year period from 2008 to 2011 over the Netherlands, for example, IASI $\mathrm{NH}_{3}$ columns are as high as $6.5 \mathrm{mg} / \mathrm{m}^{2}$, while the modeled $\mathrm{NH}_{3}$ go up to $5.2 \mathrm{mg} / \mathrm{m}^{2}$ (Van Damme et al., 2014b).

\section{Conclusions}

The FTIR spectrometer situated in downtown Toronto, Ontario, Canada, has been used to obtain a 16-year time series of total columns of $\mathrm{NH}_{3}$. These columns were compared to other $\mathrm{NH}_{3}$ observations (IASI column and NAPS in situ surface VMR) and GEOS-Chem model data. Analysis of the FTIR $\mathrm{NH}_{3}$ columns showed an upward annual trend of $3.34 \pm 0.89 \%$ and $2.23 \pm 0.62 \%$ over the period 2002 2018, with and without outliers, respectively. The larger trend with outliers included, along with a larger variance in the total column measurements in the later years, suggests that $\mathrm{NH}_{3}$ enhancements are becoming more frequent and seasonal variability is increasing. These values are in agreement with trends observed by other studies. For example, Warner et al. (2017) observed a trend of $2.61 \% / y r$ from 2002 to 2016 over the USA using data from the Atmospheric Infrared Sounder (AIRS) aboard NASA's Aqua satellite, and Yu et al. 
Table 3. IASI vs. TAO FTIR correlation coefficient, slope (regression standard error in parenthesis), MRD ( $1 \sigma \mathrm{rms}$ in parenthesis) (in $\%$ ), and number of data points, calculated for each TAO FTIR measurement, for varying spatial and temporal coincidence criteria.

\begin{tabular}{|c|c|c|c|c|}
\hline Coincidence criteria & $\leq 25 \mathrm{~km}$ & $\leq 30 \mathrm{~km}$ & $\leq 50 \mathrm{~km}$ & $\leq 100 \mathrm{~km}$ \\
\hline$\leq 20 \min$ & $\begin{array}{l}r=0.73 \\
\text { slope }=1.14(0.06) \\
\text { MRD }=-61.9 \\
(161.6) \% \\
N=314\end{array}$ & $\begin{array}{l}r=0.72 \\
\text { slope }=1.11(0.06) \\
\text { MRD }=-58.3 \\
(156.7) \% \\
N=337\end{array}$ & $\begin{array}{l}r=0.68 \\
\text { slope }=1.06(0.06) \\
\text { MRD }=-51.2 \\
(166.1) \% \\
N=384\end{array}$ & $\begin{array}{l}r=0.63 \\
\text { slope }=1.24(0.08) \\
\text { MRD }=-47.7 \\
(190.9) \% \\
N=421\end{array}$ \\
\hline$\leq 30 \mathrm{~min}$ & $\begin{array}{l}r=0.71 \\
\text { slope }=1.06(0.05) \\
\text { MRD }=-48.1 \\
(216.8) \% \\
N=438\end{array}$ & $\begin{array}{l}r=0.70 \\
\text { slope }=1.04(0.05) \\
\text { MRD }=-43.1 \\
(204.2) \% \\
N=470\end{array}$ & $\begin{array}{l}r=0.65 \\
\text { slope }=0.98(0.05) \\
\text { MRD }=-42.0 \\
(200.4) \% \\
N=528\end{array}$ & $\begin{array}{l}r=0.59 \\
\text { slope }=1.07(0.06) \\
\text { MRD }=-40.9 \\
(186.7) \% \\
N=575\end{array}$ \\
\hline$\leq 45 \mathrm{~min}$ & $\begin{array}{l}r=0.68 \\
\text { slope }=0.93(0.04) \\
\text { MRD }=-47.4 \\
(198.2) \% \\
N=588\end{array}$ & $\begin{array}{l}r=0.67 \\
\text { slope }=0.92(0.04) \\
\text { MRD }=-42.8 \\
(190.6) \% \\
N=623\end{array}$ & $\begin{array}{l}r=0.64 \\
\text { slope }=0.92(0.04) \\
\text { MRD }=-41.0 \\
(185.5) \% \\
N=679\end{array}$ & $\begin{array}{l}r=0.58 \\
\text { slope }=0.97(0.05) \\
\text { MRD }=-42.4 \\
(177.9) \% \\
N=732\end{array}$ \\
\hline$\leq 60 \mathrm{~min}$ & $\begin{array}{l}r=0.66 \\
\text { slope }=0.89(0.04) \\
\text { MRD }=-46.4 \\
(188.4) \% \\
N=708\end{array}$ & $\begin{array}{l}r=0.65 \\
\text { slope }=0.90(0.04) \\
\text { MRD }=-42.8 \\
(180.3) \% \\
N=750\end{array}$ & $\begin{array}{l}r=0.62 \\
\text { slope }=0.89(0.04) \\
\text { MRD }=-38.2 \\
(176.7) \% \\
N=815\end{array}$ & $\begin{array}{l}r=0.56 \\
\text { slope }=0.93(0.05) \\
\text { MRD }=-40.7 \\
(172.1) \% \\
N=866\end{array}$ \\
\hline$\leq 90 \mathrm{~min}$ & $\begin{array}{l}r=0.65 \\
\text { slope }=0.88(0.03) \\
\text { MRD }=-45.5 \\
(207.2) \% \\
N=923\end{array}$ & $\begin{array}{l}r=0.65 \\
\text { slope }=0.88(0.03) \\
\text { MRD }=-44.1 \\
(192.4) \% \\
N=967\end{array}$ & $\begin{array}{l}r=0.61 \\
\text { slope }=0.89(0.04) \\
\text { MRD }=-40.7 \\
(193.5) \% \\
N=1039\end{array}$ & $\begin{array}{l}r=0.56 \\
\text { slope }=0.93(0.04) \\
\text { MRD }=-36.9 \\
(186.3) \% \\
N=1093\end{array}$ \\
\hline
\end{tabular}

(a)

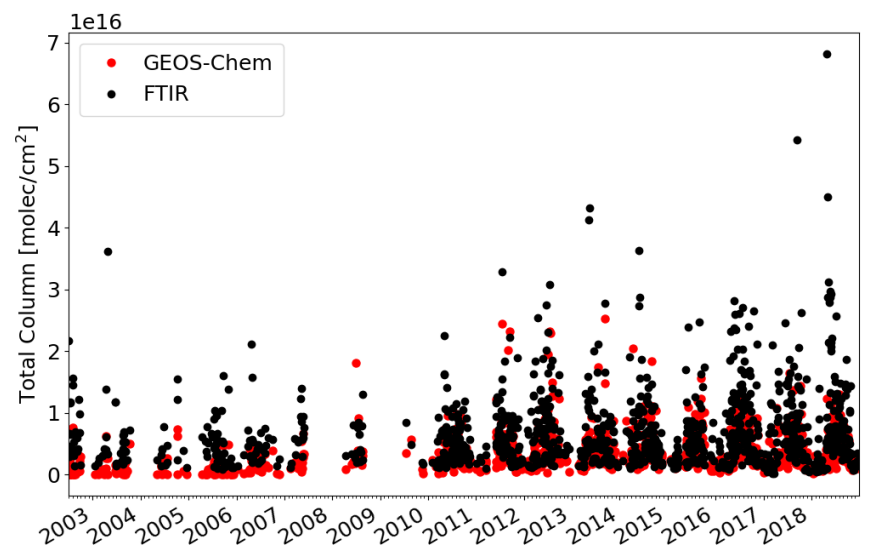

(b)

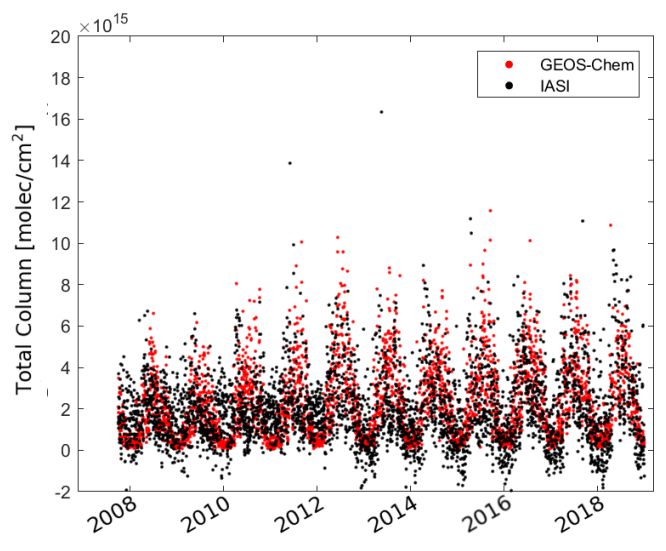

Figure 8. (a) GEOS-Chem and TAO FTIR $\mathrm{NH}_{3}$ total columns from 2002 to 2018. GEOS-Chem data shown here were not smoothed with the FTIR averaging kernel and a priori profile. (b) GEOS-Chem and IASI $\mathrm{NH}_{3}$ total columns (averaged over domain spanning from 35 to $53^{\circ} \mathrm{N}$ and 93.75 to $63.75^{\circ} \mathrm{W}$ ) from 2008 to 2018 . 
(a)

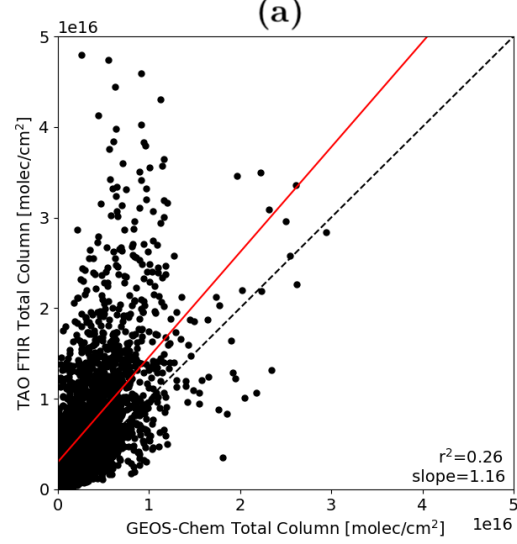

(c)

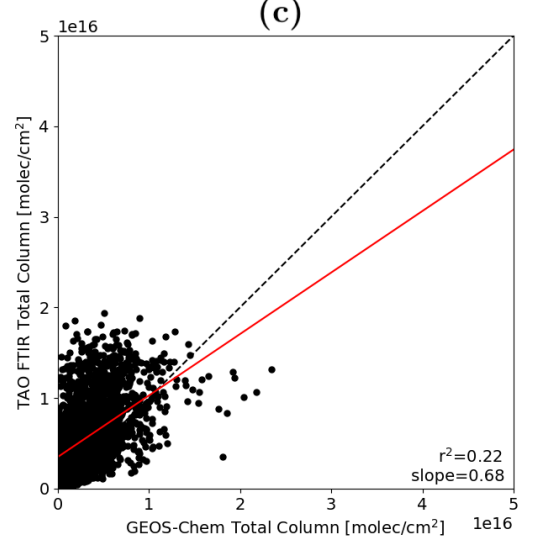

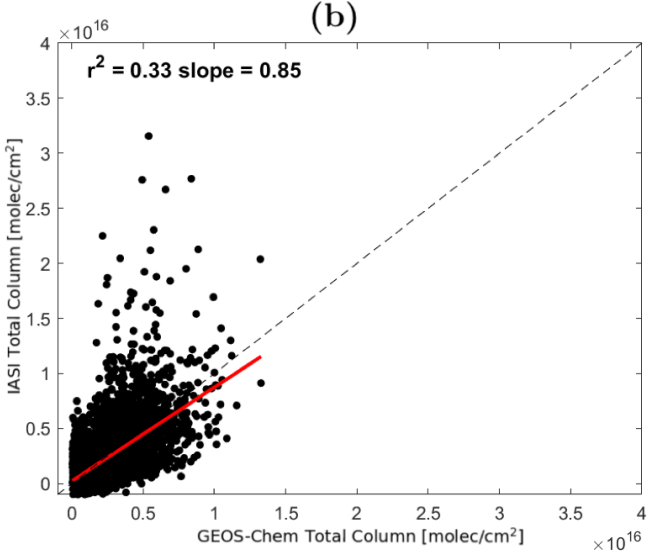

(d)

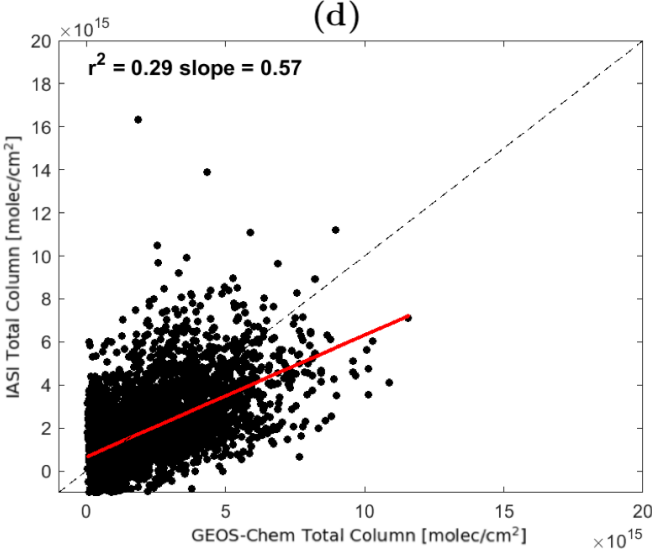

Figure 9. Correlation plots of (a) TAO FTIR vs. GEOS-Chem $\mathrm{NH}_{3}$ total columns, (b) IASI vs. GEOS-Chem $\mathrm{NH}_{3}$ total columns, (c) TAO FTIR with enhancement events removed vs. GEOS-Chem $\mathrm{NH}_{3}$ total columns, and (d) IASI with enhancement events removed vs. GEOSChem $\mathrm{NH}_{3}$ total columns. Data from 2002 to 2018 are plotted for TAO and data from 2008 to 2018 are plotted for IASI.

(2018) derived surface $\mathrm{NH}_{3}$ trends of $\sim 5 \%$ and $\sim 5 \%-12 \%$ in the western and eastern United States from 2001 to 2016, respectively, using GEOS-Chem modeled $\mathrm{NH}_{3}$.

Similar analysis of the NAPS in situ time series showed that $\mathrm{NH}_{3}$ at the surface is also increasing, with an annual increase of $8.88 \pm 5.08 \%$ and $6.40 \pm 4.37 \%$ calculated with and without outliers, respectively. The FTIR total columns during the same period showed trends of $9.31 \pm 5.73 \% / \mathrm{yr}$ and $7.42 \pm 4.48 \% / y r$ with and without outliers, respectively. The FTIR and NAPS comparisons showed that the FTIR columns are well correlated with surface $\mathrm{NH}_{3}$ when resampled to monthly means to reduce high-frequency variability.

IASI $\mathrm{NH}_{3}$ total columns measured within $50 \mathrm{~km}$ of TAO exhibited an annual trend of $8.38 \pm 1.54 \% / \mathrm{yr}$ from 2008 to 2018. For comparison, TAO FTIR $\mathrm{NH}_{3}$ total columns over the same period showed a trend of $4.02 \pm 1.42 \% / \mathrm{yr}$. The IASI columns were also compared to FTIR columns, with the good correlations being obtained with a distance criterion of $\sim 50 \mathrm{~km}$, indicating that the TAO FTIR measurements are representative of $\mathrm{NH}_{3}$ at a city-size scale. Comparing different coincidence criteria showed that, at least in Toronto, distance criteria can be larger than the $25 \mathrm{~km}$ used by Dammers et al. (2016), but temporal criteria may need to be stricter, at around $\sim 45 \mathrm{~min}$ (instead of $90 \mathrm{~min}$ ). The highest correlation $(r=0.73)$ was seen with coincidence criteria of $25 \mathrm{~km}$ and 20 min.

TAO FTIR and IASI $\mathrm{NH}_{3}$ columns were also compared with GEOS-Chem model data. The model did not show a very high correlation with the TAO FTIR for a single grid cell containing Toronto, with $r^{2}=0.26$ and $r^{2}=0.28$ when the model data were smoothed with the FTIR averaging kernel. The model comparison with IASI showed slightly better agreement on a domain spanning 35 to $53^{\circ} \mathrm{N}$ and 93.75 to $63.75^{\circ} \mathrm{W}$, with $r^{2}=0.33$. These results suggest that TAO FTIR, representative of $\mathrm{NH}_{3}$ at a city-size scale $(\sim 50 \mathrm{~km})$, requires higher-resolution model runs for comparison. This is also evident when comparing GEOS-Chem to IASI within the single model grid cell that includes TAO; this comparison led to a poorer correlation with $r^{2}=0.13$. In addition, GEOS-Chem overestimated $\mathrm{NH}_{3}$ in the larger domain when compared with IASI. However, in the single grid cell over TAO, the model underestimated $\mathrm{NH}_{3}$ columns compared to both IASI and TAO FTIR. 
This study showed a positive trend of $\mathrm{NH}_{3}$ over Toronto derived from ground-based FTIR, satellite, and in situ measurements. The $\mathrm{NH}_{3}$ total columns using an FTIR situated in downtown Toronto are representative of a city-size scale, although this also highlights the need for models simulating $\mathrm{NH}_{3}$ to be run at higher resolution than $2^{\circ} \times 2.5^{\circ}$ for comparisons with ground-based measurements.

Code availability. The SFIT4 retrieval code can be accessed at https://wiki.ucar.edu/display/sfit4/ (described in text) (Hannigan et al., 2020). The latest model information can be found at https://doi.org/10.5281/zenodo.3959279 (The International GEOSChem User Community, 2020). Instructions for downloading and running the models can be found at http://wiki.geos-chem.org/ (last access: 1 November 2020). The GEOS-Chem model (v11-01) is freely available to the public.

Data availability. The TAO FTIR data used in this study are publicly available from the NDACC data repository hosted by NOAA at https://www.ndaccdemo.org/stations/toronto-canada (NDACC, 2021). The IASI Level-1C data are distributed in near real time by Eumetsat through the EumetCast system distribution (https://www. eumetsat.int/eumetcast) (EUMETSAT, 2021). The IASI ANNINH3-v3 data used in this study are available from the Aeris data infrastructure: http://iasi.aeris-data.fr/NH3 (Van Damme et al., 2021). The in situ $\mathrm{NH}_{3}$ data measured by the Canadian National Air Pollution Surveillance (NAPS) are available at https://open.canada.ca/ data/en/dataset/1b36a356-defd-4813-acea-47bc3abd859b (ECCC, 2019), provided by Environment and Climate Change Canada.

Author contributions. SY, CV, and KS conceived this study. SY wrote the paper with contributions from all authors. EL and SY performed the retrieval of $\mathrm{NH}_{3}$ columns at TAO. SY ran the GEOSChem model with guidance from DBAJ. SY and CV performed the analyses and comparisons of $\mathrm{NH}_{3}$ measurements around Toronto. MVD and LC performed IASI retrievals, and CV analyzed the IASI retrievals with guidance from $\mathrm{CC}$ and PFC. All of the authors discussed the results and contributed to the final paper.

Competing interests. The authors declare that they have no conflict of interest.

Acknowledgements. This project was made possible thanks to the 2018 Centre National de la Recherche Scientifique - University of Toronto Call for Joint Research Proposals, which provided the initial support for the AmmonAQ project. IASI is a joint mission of EUMETSAT and the Centre National d'Etudes Spatiales (CNES, France). The authors acknowledge the Aeris data infrastructure (http://iasi.aeris-data.fr/NH3/, last access: 25 January 2021) for providing access to the IASI data as well as Environment and Climate Change Canada for the NAPS in situ data. ULB has been supported by the Belgian State Federal Office for Scientific, Technical and Cultural Affairs (Prodex arrangement IASI.FLOW).
Lieven Clarisse and Martin Van Damme are, respectively, research associate and postdoctoral researcher with the Belgian F. R. SFNRS.

Financial support. This research has been supported by the University of Toronto - Centre National de la Recherche Scientifique, the Natural Sciences and Engineering Research Council of Canada (NSERC, grant no. RGPIN-2019-06979), the NSERC CREATE Training Program in Technologies for Exo-Planetary Science (grant no. CREATE-482699-2016), and Environment and Climate Change Canada (grant no. GCXE19S039).

Review statement. This paper was edited by Hendrik Fuchs and reviewed by two anonymous referees.

\section{References}

Angelbratt, J., Mellqvist, J., Blumenstock, T., Borsdorff, T., Brohede, S., Duchatelet, P., Forster, F., Hase, F., Mahieu, E., Murtagh, D., Petersen, A. K., Schneider, M., Sussmann, R., and Urban, J.: A new method to detect long term trends of methane $\left(\mathrm{CH}_{4}\right)$ and nitrous oxide $\left(\mathrm{N}_{2} \mathrm{O}\right)$ total columns measured within the NDACC ground-based high resolution solar FTIR network, Atmos. Chem. Phys., 11, 6167-6183, https://doi.org/10.5194/acp-11-6167-2011, 2011.

Bobbink, R., Hicks, K., Galloway, J., Spranger, T., Alkemade, R., Ashmore, M., Bustamante, M., Cinderby, S., Davidson, E., Dentener, F., Emmett, B., Erisman, J.-W., Fenn, M., Gilliam, F., Nordin, A., Pardo, L., and De Vries, W.: Global assessment of nitrogen deposition effects on terrestrial plant diversity: a synthesis, Ecol. Appl., 20, 30-59, https://doi.org/10.1890/08-1140.1, 2010.

Bouwman, A. F., Lee, D. S., Asman, W. A. H., Dentener, F. J., Van Der Hoek, K. W., and Olivier, J. G. J.: A global high-resolution emission inventory for ammonia, Glob. Biogeochem. Cy., 11, 561-587, https://doi.org/10.1029/97GB02266, 1997.

Clarisse, L., Van Damme, M., Clerbaux, C., and Coheur, P.F.: Tracking down global $\mathrm{NH}_{3}$ point sources with windadjusted superresolution, Atmos. Meas. Tech., 12, 5457-5473, https://doi.org/10.5194/amt-12-5457-2019 2019a.

Clarisse, L., Van Damme, M., Gardner, W., Coheur, P.-F., Clerbaux, C., Whitburn, S., Hadji-Lazaro, J., and Hurtmans, D.: Atmospheric ammonia $\left(\mathrm{NH}_{3}\right)$ emanations from Lake Natron's saline mudflats, Sci. Rep.-UK, 9, 4441-4452, https://doi.org/10.1038/s41598-019-39935-3, 2019b.

Clerbaux, C., Boynard, A., Clarisse, L., George, M., Hadji-Lazaro, J., Herbin, H., Hurtmans, D., Pommier, M., Razavi, A., Turquety, S., Wespes, C., and Coheur, P.-F.: Monitoring of atmospheric composition using the thermal infrared IASI/MetOp sounder, Atmos. Chem. Phys., 9, 6041-6054, https://doi.org/10.5194/acp-96041-2009, 2009.

Croft, B., Wentworth, G. R., Martin, R. V., Leaitch, W. R., Murphy, J. G., Murphy, B. N., Kodros, J. K., Abbatt, J. P. D., and Pierce, J. R.: Contribution of Arctic seabird-colony ammonia to atmospheric particles and cloud-albedo radiative effect, Nat. Commun., 7, 13444, https://doi.org/10.1038/ncomms13444, 2016. 
Dammers, E., Vigouroux, C., Palm, M., Mahieu, E., Warneke, T., Smale, D., Langerock, B., Franco, B., Van Damme, M., Schaap, M., Notholt, J., and Erisman, J. W.: Retrieval of ammonia from ground-based FTIR solar spectra, Atmos. Chem. Phys., 15, 12789-12803, https://doi.org/10.5194/acp-15-127892015, 2015.

Dammers, E., Palm, M., Van Damme, M., Vigouroux, C., Smale, D., Conway, S., Toon, G. C., Jones, N., Nussbaumer, E., Warneke, T., Petri, C., Clarisse, L., Clerbaux, C., Hermans, C., Lutsch, E., Strong, K., Hannigan, J. W., Nakajima, H., Morino, I., Herrera, B., Stremme, W., Grutter, M., Schaap, M., Wichink Kruit, R. J., Notholt, J., Coheur, P.-F., and Erisman, J. W.: An evaluation of IASI-NH3 with ground-based Fourier transform infrared spectroscopy measurements, Atmos. Chem. Phys., 16, 10351-10368, https://doi.org/10.5194/acp-16-10351-2016, 2016.

Dammers, E., McLinden, C. A., Griffin, D., Shephard, M. W., Van Der Graaf, S., Lutsch, E., Schaap, M., Gainairu-Matz, Y., Fioletov, V., Van Damme, M., Whitburn, S., Clarisse, L., CadyPereira, K., Clerbaux, C., Coheur, P. F., and Erisman, J. W.: $\mathrm{NH}_{3}$ emissions from large point sources derived from CrIS and IASI satellite observations, Atmos. Chem. Phys., 19, 12261-12293, https://doi.org/10.5194/acp-19-12261-2019, 2019.

De Mazière, M., Thompson, A. M., Kurylo, M. J., Wild, J. D., Bernhard, G., Blumenstock, T., Braathen, G. O., Hannigan, J. W., Lambert, J.-C., Leblanc, T., McGee, T. J., Nedoluha, G., Petropavlovskikh, I., Seckmeyer, G., Simon, P. C., Steinbrecht, W., and Strahan, S. E.: The Network for the Detection of Atmospheric Composition Change (NDACC): history, status and perspectives, Atmos. Chem. Phys., 18, 4935-4964, https://doi.org/10.5194/acp-18-4935-2018, 2018.

Environment and Climate Change Canada (ECCC): National Air Pollution Surveillance Program, available at: https://open.canada.ca/data/en/dataset/ 1b36a356-defd-4813-acea-47bc3abd859b, (last access: 25 January 2021), 2019.

Erisman, J. W., Sutton, M. A., Galloway, J., Klimont, Z., and Winiwarter, W.: How a century of ammonia synthesis changed the world, Nat. Geosci., 1, 636-639, https://doi.org/10.1038/ngeo325, 2008.

EUMETSAT: EUMETCast, available at: https://www.eumetsat.int/ eumetcast, last access: 25 January 2021.

Fortems-Cheiney, A., Dufour, G., Hamaoui-Laguel, L., Foret, G., Siour, G., Van Damme, M., Meleux, F., Coheur, P.F., Clerbaux, C., Clarisse, L., Favez, O., Wallasch, M., and Beekmann, M.: Unaccounted variability in $\mathrm{NH}_{3}$ agricultural sources detected by IASI contributing to European spring haze episode, Geophys. Res. Lett., 43, 5475-5482, https://doi.org/10.1002/2016GL069361, 2016.

Fountoukis, C. and Nenes, A.: ISORROPIA II: a computationally efficient thermodynamic equilibrium model for $\mathrm{K}^{+}$ $\mathrm{Ca}^{2+}-\mathrm{Mg}^{2+}-\mathrm{NH}_{4}{ }^{+}-\mathrm{Na}^{+}-\mathrm{SO}_{4}{ }^{2-}-\mathrm{NO}_{3}{ }^{-}-\mathrm{Cl}^{-}-\mathrm{H}_{2} \mathrm{O}$ aerosols, Atmos. Chem. Phys., 7, 4639-4659, https://doi.org/10.5194/acp7-4639-2007, 2007.

Franco, B., Clarisse, L., Stavrakou, T., Müller, J.-F., Van Damme, M., Whitburn, S., Hadji-Lazaro, J., Hurtmans, D., Taraborrelli, D., Clerbaux, C., and Coheur, P.-F.: A General Framework for Global Retrievals of Trace Gases From IASI: Application to Methanol, Formic Acid, and PAN, J. Geophys. Res.-Atmos., 123, 13963-13984, https://doi.org/10.1029/2018JD029633, 2018.
Franklin, J.: Solar Absorption Spectroscopy at the Dalhousie Atmospheric Observatory, PhD thesis, Dalhousie University, Halifax, Nova Scotia, Canada, 2015.

Galloway, J. N., Aber, J. D., Erisman, J. W., Seitzinger, S. P., Howarth, R. W., Cowling, E. B., and Cosby, B. J.: The Nitrogen Cascade, Bioscience, 53, 341-356, https://doi.org/10.1641/00063568(2003)053[0341:TNC]2.0.CO;2, 2003.

Gardiner, T., Forbes, A., de Mazière, M., Vigouroux, C., Mahieu, E., Demoulin, P., Velazco, V., Notholt, J., Blumenstock, T., Hase, F., Kramer, I., Sussmann, R., Stremme, W., Mellqvist, J., Strandberg, A., Ellingsen, K., and Gauss, M.: Trend analysis of greenhouse gases over Europe measured by a network of ground-based remote FTIR instruments, Atmos. Chem. Phys., 8, 6719-6727, https://doi.org/10.5194/acp-8-6719-2008, 2008.

Giannadaki, D., Pozzer, A., and Lelieveld, J.: Modeled global effects of airborne desert dust on air quality and premature mortality, Atmos. Chem. Phys., 14, 957-968, https://doi.org/10.5194/acp-14-957-2014, 2014.

Griffin, D., Walker, K. A., Franklin, J. E., Parrington, M., Whaley, C., Hopper, J., Drummond, J. R., Palmer, P. I., Strong, K., Duck, T. J., Abboud, I., Bernath, P. F., Clerbaux, C., Coheur, P.F., Curry, K. R., Dan, L., Hyer, E., Kliever, J., Lesins, G., Maurice, M., Saha, A., Tereszchuk, K., and Weaver, D.: Investigation of $\mathrm{CO}, \mathrm{C}_{2} \mathrm{H}_{6}$ and aerosols in a boreal fire plume over eastern Canada during BORTAS 2011 using ground- and satellitebased observations and model simulations, Atmos. Chem. Phys., 13, 10227-10241, https://doi.org/10.5194/acp-13-10227-2013, 2013.

Hannigan, J., Palm, M., and Ortega, I.: Infrared Working Group Retrieval Code, SFIT, available at: https://wiki.ucar.edu/display/ sfit4/, last access 1 November 2020.

Höpfner, M., Volkamer, R., Grabowski, U., Grutter, M., Orphal, J., Stiller, G., von Clarmann, T., and Wetzel, G.: First detection of ammonia $\left(\mathrm{NH}_{3}\right)$ in the Asian summer monsoon upper troposphere, Atmos. Chem. Phys., 16, 14357-14369, https://doi.org/10.5194/acp-16-14357-2016, 2016.

Hu, Q., Zhang, L., Evans, G. J., and Yao, X.: Variability of atmospheric ammonia related to potential emission sources in downtown Toronto, Canada, Atmos. Environ., 99, 365-373, https://doi.org/10.1016/j.atmosenv.2014.10.006, 2014.

Janssens-Maenhout, G., Crippa, M., Guizzardi, D., Muntean, M., Schaaf, E., Dentener, F., Bergamaschi, P., Pagliari, V., Olivier, J. G. J., Peters, J. A. H. W., van Aardenne, J. A., Monni, S., Doering, U., Petrescu, A. M. R., Solazzo, E., and Oreggioni, G. D.: EDGAR v4.3.2 Global Atlas of the three major greenhouse gas emissions for the period 1970-2012, Earth Syst. Sci. Data, 11, 959-1002, https://doi.org/10.5194/essd-11-959-2019, 2019.

Krupa, S.: Atmosphere and agriculture in the new millennium, Environ. Pollut., 126, 293-300, https://doi.org/10.1016/S02697491(03)00242-2, 2003.

Lachatre, M., Fortems-Cheiney, A., Foret, G., Siour, G., Dufour, G., Clarisse, L., Clerbaux, C., Coheur, P.-F., Van Damme, M., and Beekmann, M.: The unintended consequence of $\mathrm{SO}_{2}$ and $\mathrm{NO}_{2}$ regulations over China: increase of ammonia levels and impact on PM2.5 concentrations, Atmos. Chem. Phys., 19, 6701-6716, https://doi.org/10.5194/acp-19-6701-2019, 2019.

Li, Y., Schwandner, F. M., Sewell, H. J., Zivkovich, A., Tigges, M., Raja, S., Holcomb, S., Molenar, J. V., Sherman, L., Archuleta, C., Lee, T., and Collett, J. L.: Observa- 
tions of ammonia, nitric acid, and fine particles in a rural gas production region, Atmospheric Environment, 83, 80-89, https://doi.org/10.1016/j.atmosenv.2013.10.007, 2014.

Liu, L., Zhang, X., Xu, W., Liu, X., Lu, X., Wang, S., Zhang, W., and Zhao, L.: Ground Ammonia Concentrations over China Derived from Satellite and Atmospheric Transport Modeling, Remote Sens., 9, 247, https://doi.org/10.3390/rs9050467, 2017.

Liu, M., Huang, X., Song, Y., Tang, J., Cao, J., Zhang, X., Zhang, Q., Wang, S., Xu, T., Kang, L., Cai, X., Zhang, H., Yang, F., Wang, H., Yu, J. Z., Lau, A. K. H., He, L., Huang, X., Duan, L., Ding, A., Xue, L., Gao, J., Liu, B., and Zhu, T.: Ammonia emission control in China would mitigate haze pollution and nitrogen deposition, but worsen acid rain, P. Natl. Acad. Sci. USA, 116, 7760-7765, https://doi.org/10.1073/pnas.1814880116, 2019.

Lutsch, E., Dammers, E., Conway, S., and Strong, K.: Longrange transport of $\mathrm{NH}_{3}, \mathrm{CO}, \mathrm{HCN}$, and $\mathrm{C}_{2} \mathrm{H}_{6}$ from the 2014 Canadian Wildfires, Geophys. Res. Lett., 43, 8286-8297, https://doi.org/10.1002/2016GL070114, 2016.

Lutsch, E., Strong, K., Jones, D. B. A., Ortega, I., Hannigan, J. W., Dammers, E., Shephard, M. W., Morris, E., Murphy, K., Evans, M. J., Parrington, M., Whitburn, S., Van Damme, M., Clarisse, L., Coheur, P.-F., Clerbaux, C., Croft, B., Martin, R. V., Pierce, J. R., and Fisher, J. A.: Unprecedented Atmospheric Ammonia Concentrations Detected in the High Arctic From the 2017 Canadian Wildfires, J. Geophys. Res.-Atmos., 124, 8178-8202, https://doi.org/10.1029/2019JD030419, 2019.

Lutsch, E., Strong, K., Jones, D. B. A., Blumenstock, T., Conway, S., Fisher, J. A., Hannigan, J. W., Hase, F., Kasai, Y., Mahieu, E., Makarova, M., Morino, I., Nagahama, T., Notholt, J., Ortega, I., Palm, M., Poberovskii, A. V., Sussmann, R., and Warneke, T.: Detection and attribution of wildfire pollution in the Arctic and northern midlatitudes using a network of Fourier-transform infrared spectrometers and GEOS-Chem, Atmos. Chem. Phys., 20, 12813-12851, https://doi.org/10.5194/acp-20-12813-2020, 2020.

Meng, Z. Y., Lin, W. L., Jiang, X. M., Yan, P., Wang, Y., Zhang, Y. M., Jia, X. F., and Yu, X. L.: Characteristics of atmospheric ammonia over Beijing, China, Atmos. Chem. Phys., 11, 61396151, https://doi.org/10.5194/acp-11-6139-2011, 2011.

Molod, A., Takacs, L., Suarez, M., and Bacmeister, J.: Development of the GEOS-5 atmospheric general circulation model: evolution from MERRA to MERRA2, Geosci. Model Dev., 8, 1339-1356, https://doi.org/10.5194/gmd-8-1339-2015, 2015.

Munroe, J., Brown, C., Kessel, C., Verhallen, A., Lauzon, J., O'Halloran, I., Bruulsema, T., and Cowan, D.: Soil Fertility Handbook Publication 611, Ministry of Agriculture, Food and Rural Affairs (OMAFRA), 3 edn., available at: http://www. omafra.gov.on.ca/english/crops/pub611/pub611.pdf (last access: 25 January 2021), 2018.

Network for the Detection of Atmospheric Composition Change (NDACC): NDACC Measurements at the Toronto, Canada Station, available at: https://www.ndaccdemo.org/stations/ toronto-canada, last access: 25 January 2021.

Olivier, J., Bouwman, A., Van der Hoek, K., and Berdowski, J.: Global air emission inventories for anthropogenic sources of $\mathrm{NO}_{x}, \mathrm{NH}_{3}$ and $\mathrm{N}_{2} \mathrm{O}$ in 1990, Environ. Pollut., 102, 135-148, https://doi.org/10.1016/S0269-7491(98)80026-2, 1998.

Park, R. J., Jacob, D. J., Field, B. D., Yantosca, R. M., and Chin, M.: Natural and transboundary pollution influences on sulfate-nitrate-ammonium aerosols in the United States: Implications for policy, J. Geophys. Res.-Atmos., 109, D15204, https://doi.org/10.1029/2003JD004473, 2004.

Pope, C. A., Ezzati, M., and Dockery, D. W.: Fine-Particulate Air Pollution and Life Expectancy in the United States, New Engl. J. Med., 360, 376-386, https://doi.org/10.1056/NEJMsa0805646, 2009.

Pozzer, A., Tsimpidi, A. P., Karydis, V. A., de Meij, A., and Lelieveld, J.: Impact of agricultural emission reductions on fine-particulate matter and public health, Atmos. Chem. Phys., 17, 12813-12826, https://doi.org/10.5194/acp-17-12813-2017, 2017.

Rodgers, C. D.: Inverse Methods for Atmospheric Sounding, 2, 81100, World Scientific, https://doi.org/10.1142/3171, 2000.

Rodgers, C. D. and Connor, B. J.: Intercomparison of remote sounding instruments, J. Geophys. Res.-Atmos., 108, 4116, https://doi.org/10.1029/2002JD002299, 2003.

Rothman, L., Gordon, I., Barbe, A., Benner, D., Bernath, P., Birk, M., Boudon, V., Brown, L., Campargue, A., Champion, J.-P., Chance, K., Coudert, L., Dana, V., Devi, V., Fally, S., Flaud, J.-M., Gamache, R., Goldman, A., Jacquemart, D., Kleiner, I., Lacome, N., Lafferty, W., Mandin, J.-Y., Massie, S., Mikhailenko, S., Miller, C., Moazzen-Ahmadi, N., Naumenko, O., Nikitin, A., Orphal, J., Perevalov, V., Perrin, A., Predoi-Cross, A., Rinsland, C., Rotger, M., Šimečková, M., Smith, M., Sung, K., Tashkun, S., Tennyson, J., Toth, R., Vandaele, A., and Auwera, J. V.: The HITRAN 2008 molecular spectroscopic database, J. Quant. Spectrosc. Ra., 110, 533-572, https://doi.org/10.1016/j.jqsrt.2009.02.013, 2009.

Schaap, M., van Loon, M., ten Brink, H. M., Dentener, F. J., and Builtjes, P. J. H.: Secondary inorganic aerosol simulations for Europe with special attention to nitrate, Atmos. Chem. Phys., 4, 857-874, https://doi.org/10.5194/acp-4-857-2004, 2004.

Schiferl, L. D., Heald, C. L., Nowak, J. B., Holloway, J. S., Neuman, J. A., Bahreini, R., Pollack, I. B., Ryerson, T. B., Wiedinmyer, C., and Murphy, J. G.: An investigation of ammonia and inorganic particulate matter in California during the CalNex campaign, J. Geophys. Res.-Atmos., 119, 1883-1902, https://doi.org/10.1002/2013JD020765, 2014.

Schiferl, L. D., Heald, C. L., Van Damme, M., Clarisse, L., Clerbaux, C., Coheur, P.-F., Nowak, J. B., Neuman, J. A., Herndon, S. C., Roscioli, J. R., and Eilerman, S. J.: Interannual variability of ammonia concentrations over the United States: sources and implications, Atmos. Chem. Phys., 16, 1230512328, https://doi.org/10.5194/acp-16-12305-2016, 2016.

Shephard, M. W., Dammers, E., Cady-Pereira, K. E., Kharol, S. K., Thompson, J., Gainariu-Matz, Y., Zhang, J., McLinden, C. A., Kovachik, A., Moran, M., Bittman, S., Sioris, C. E., Griffin, D., Alvarado, M. J., Lonsdale, C., Savic-Jovcic, V., and Zheng, Q.: Ammonia measurements from space with the Crosstrack Infrared Sounder: characteristics and applications, Atmos. Chem. Phys., 20, 2277-2302, https://doi.org/10.5194/acp-202277-2020, 2020.

The International GEOS-Chem User Community: geoschem/geos-chem: GEOS-Chem 12.9.2, https://doi.org/10.5281/zenodo.3959279, 2020.

Toon, G. C., Blavier, J.-F., Sen, B., Margitan, J. J., Webster, C. R., May, R. D., Fahey, D., Gao, R., Del Negro, L., Proffitt, M., Elkins, J., Romashkin, P. A., Hurst, D. F., Oltmans, 
S., Atlas, E., Schauffler, S., Flocke, F., Bui, T. P., Stimpfle, R. M., Bonne, G. P., Voss, P. B., and Cohen, R. C.: Comparison of MkIV balloon and ER-2 aircraft measurements of atmospheric trace gases, J. Geophys. Res.-Atmos., 104, 26779-26790, https://doi.org/10.1029/1999JD900379, 1999.

Tournadre, B., Chelin, P., Ray, M., Cuesta, J., Kutzner, R. D., Landsheere, X., Fortems-Cheiney, A., Flaud, J.-M., Hase, F., Blumenstock, T., Orphal, J., Viatte, C., and Camy-Peyret, C.: Atmospheric ammonia $\left(\mathrm{NH}_{3}\right)$ over the Paris megacity: 9 years of total column observations from ground-based infrared remote sensing, Atmos. Meas. Tech., 13, 3923-3937, https://doi.org/10.5194/amt-13-3923-2020, 2020.

Van Damme, M., Clarisse, L., Heald, C. L., Hurtmans, D., Ngadi, Y., Clerbaux, C., Dolman, A. J., Erisman, J. W., and Coheur, P. F.: Global distributions, time series and error characterization of atmospheric ammonia $\left(\mathrm{NH}_{3}\right)$ from IASI satellite observations, Atmos. Chem. Phys., 14, 2905-2922, https://doi.org/10.5194/acp14-2905-2014, 2014a.

Van Damme, M., Wichink Kruit, R., Schaap, M., Clarisse, L., Clerbaux, C., Coheur, P.-F., Dammers, E., Dolman, A., and Erisman, J.: Evaluating 4 years of atmospheric ammonia $\left(\mathrm{NH}_{3}\right)$ over Europe using IASI satellite observations and LOTOSEUROS model results, J. Geophys. Res.-Atmos., 119, 95499566, https://doi.org/10.1002/2014JD021911, 2014b.

Van Damme, M., Clarisse, L., Dammers, E., Liu, X., Nowak, J. B., Clerbaux, C., Flechard, C. R., Galy-Lacaux, C., Xu, W., Neuman, J. A., Tang, Y. S., Sutton, M. A., Erisman, J. W., and Coheur, P. F.: Towards validation of ammonia $\left(\mathrm{NH}_{3}\right)$ measurements from the IASI satellite, Atmos. Meas. Tech., 8, 15751591, https://doi.org/10.5194/amt-8-1575-2015, 2015 a.

Van Damme, M., Erisman, J. W., Clarisse, L., Dammers, E., Whitburn, S., Clerbaux, C., Dolman, A. J., and Coheur, P.-F.: Worldwide spatiotemporal atmospheric ammonia $\left(\mathrm{NH}_{3}\right)$ columns variability revealed by satellite, Geophys. Res. Lett., 42, 8660-8668, https://doi.org/10.1002/2015GL065496, 2015b.

Van Damme, M., Whitburn, S., Clarisse, L., Clerbaux, C., Hurtmans, D., and Coheur, P.-F.: Version 2 of the IASI NH3 neural network retrieval algorithm: near-real-time and reanalysed datasets, Atmos. Meas. Tech., 10, 4905-4914, https://doi.org/10.5194/amt-10-4905-2017, 2017.

Van Damme, M., Clarisse, L., Whitburn, S., Hadji-Lazaro, J., Hurtmans, D., Clerbaux, C., and Coheur, P.-F.: Industrial and agricultural ammonia point sources exposed, Nature, 564, 99-103, https://doi.org/10.1038/s41586-018-0747-1, 2018.

Van Damme, M., Clarisse, L., Franco, B., Sutton, M. A., Erisman, J. W., Wichink Kruit, R., van Zanten, M., Whitburn, S., Hadji-Lazaro, J., Hurtmans, D., Clerbaux, C., and Coheur, P.F.: Global, regional and national trends of atmospheric ammonia derived from a decadal (2008-2018) satellite record, Environ. Res. Lett., https://doi.org/10.1088/1748-9326/abd5e0, accepted, 2021 (data available at: http://iasi.aeris-data.fr/NH3, last access: 25 January 2021).

van Vuuren, D. P., Edmonds, J., Kainuma, M., Riahi, K., Thomson, A., Hibbard, K., Hurtt, G. C., Kram, T., Krey, V., Lamarque, J.-F., Masui, T., Meinshausen, M., Nakicenovic, N., Smith, S. J., and Rose, S. K.: The representative concentration pathways: an overview, Climatic Change, 109, 5, https://doi.org/10.1007/s10584-011-0148-z, 2011.
Viatte, C., Wang, T., Van Damme, M., Dammers, E., Meleux, F., Clarisse, L., Shephard, M. W., Whitburn, S., Coheur, P. F., Cady-Pereira, K. E., and Clerbaux, C.: Atmospheric ammonia variability and link with particulate matter formation: a case study over the Paris area, Atmos. Chem. Phys., 20, 577-596, https://doi.org/10.5194/acp-20-577-2020, 2020.

Vitousek, P. M., Mooney, H. A., Lubchenco, J., and Melillo, J. M.: Human Domination of Earth's Ecosystems, Science, 277, 494499, https://doi.org/10.1126/science.277.5325.494, 1997.

Warner, J. X., Wei, Z., Strow, L. L., Dickerson, R. R., and Nowak, J. B.: The global tropospheric ammonia distribution as seen in the 13-year AIRS measurement record, Atmos. Chem. Phys., 16, 5467-5479, https://doi.org/10.5194/acp-16-5467-2016, 2016.

Warner, J. X., Dickerson, R. R., Wei, Z., Strow, L. L., Wang, Y., and Liang, Q.: Increased atmospheric ammonia over the world's major agricultural areas detected from space, Geophys. Res. Lett., 44, 2875-2884, https://doi.org/10.1002/2016GL072305, 2017.

Weatherhead, E. C., Reinsel, G. C., Tiao, G. C., Meng, X.-L., Choi, D., Cheang, W.-K., Keller, T., DeLuisi, J., Wuebbles, D. J., Kerr, J. B., Miller, A. J., Oltmans, S. J., and Frederick, J. E.: Factors affecting the detection of trends: Statistical considerations and applications to environmental data, J. Geophys. Res.-Atmos., 103, 17149-17161, https://doi.org/10.1029/98JD00995, 1998.

Wentworth, G. R., Murphy, J. G., Gregoire, P. K., Cheyne, C. A. L., Tevlin, A. G., and Hems, R.: Soil-atmosphere exchange of ammonia in a non-fertilized grassland: measured emission potentials and inferred fluxes, Biogeosciences, 11, 5675-5686, https://doi.org/10.5194/bg-11-5675-2014, 2014.

Whaley, C. H., Strong, K., Jones, D. B. A., Walker, T. W., Jiang, Z., Henze, D. K., Cooke, M. A., McLinden, C. A., Mittermeier, R. L., Pommier, M., and Fogal, P. F.: Toronto area ozone: Long-term measurements and modeled sources of poor air quality events, J. Geophys. Res.-Atmos., 120, 11368-11390, https://doi.org/10.1002/2014JD022984, 2015.

Whitburn, S., Van Damme, M., Clarisse, L., Bauduin, S., Heald, C. L., Hadji-Lazaro, J., Hurtmans, D., Zondlo, M. A., Clerbaux, C., and Coheur, P.-F.: A flexible and robust neural network IASI$\mathrm{NH}_{3}$ retrieval algorithm, J. Geophys. Res.-Atmos., 121, 65816599, https://doi.org/10.1002/2016JD024828, 2016.

Wiacek, A., Taylor, J. R., Strong, K., Saari, R., Kerzenmacher, T. E., Jones, N. B., and Griffith, D. W. T.: Ground-Based Solar Absorption FTIR Spectroscopy: Characterization of Retrievals and First Results from a Novel Optical Design Instrument at a New NDACC Complementary Station, J. Atmos. Ocean. Techn., 24, 432-448, https://doi.org/10.1175/JTECH1962.1, 2007.

Wielgosiński, G. and Czerwińska, J.: Smog Episodes in Poland, Atmosphere-Basel, 11, 277, https://doi.org/10.3390/atmos11030277, 2020.

Yao, X. and Zhang, L.: Trends in atmospheric ammonia at urban, rural, and remote sites across North America, Atmos. Chem. Phys., 16, 11465-11475, https://doi.org/10.5194/acp-16-114652016, 2016.

Yao, X. H. and Zhang, L.: Analysis of passive-sampler monitored atmospheric ammonia at 74 sites across southern Ontario, Canada, Biogeosciences, 10, 7913-7925, https://doi.org/10.5194/bg-10-7913-2013, 2013.

York, D., Evensen, N. M., Martinez, M. L., and De Basabe Delgado, J.: Unified equations for the slope, intercept, and stan- 
dard errors of the best straight line, Am. J. Phys., 72, 367-375, https://doi.org/10.1119/1.1632486, 2004.

Yu, F., Nair, A. A., and Luo, G.: Long-Term Trend of Gaseous Ammonia Over the United States: Modeling and Comparison With Observations, J. Geophys. Res.-Atmos., 123, 8315-8325, https://doi.org/10.1029/2018JD028412, 2018.

Zbieranowski, A. L. and Aherne, J.: Ambient concentrations of atmospheric ammonia, nitrogen dioxide and nitric acid across a rural-urban-agricultural transect in southern Ontario, Canada, Atmos. Environ., 62, 481-491, https://doi.org/10.1016/j.atmosenv.2012.08.040, 2012.
Zellweger, C., Hüglin, C., Klausen, J., Steinbacher, M., Vollmer, M., and Buchmann, B.: Inter-comparison of four different carbon monoxide measurement techniques and evaluation of the long-term carbon monoxide time series of Jungfraujoch, Atmos. Chem. Phys., 9, 3491-3503, https://doi.org/10.5194/acp-9-34912009, 2009. 